\title{
ANÁLISE COMPARATIVA ENTRE O SISTEMA PROCESSUAL COMUNITÁRIO E DA INTEGRAÇAO
}

Roberto Luiz Silva"

SUMARIO: 1.hroduço. 2. A Unito Européta. 21. O Sistena Jundico Comuntario. 2.2. O Regime Processual Comunitario. 22.1. Protesso Comum. 22.1.1. Acão por Descumprinento. 2.2.1.2. Acao por Omissá 2.21.3. Acto de Responsabilidade Extracontratud. 2.2.1.4. Recurso de Anulaţo. 2.2.1.5. Recurso de Funcionatos. 2.2.1.6. Renvio Prejudicial 2.2.2. Processo Especial. 3. O Mercosul. 3.1. O Sistema Juridion Integracionista. 3.2. Solucăo de Controvérsias. 4. Condusän. 5. Biblografia.

SUMMARY: 1.Introduction. 2. the European Union. 2.1. the Judicial Communty System 2.2. the Processual Community Regim. 2.2.1. I Common Process. 2.2.1.1. Action for Inexecution. 2.2.12. Action for Omission. 2.2.1.3. Action of Extracontratual Responsability. 2.2.1.4. Annulment Resoume 2.2.1.5. Employees resource. 22.2.6. Prefudicial Retum. 2.2.2. Spacid Process. 3. Mercosul. 3.1. The Jundical System Integrityolder. 3.2. Controversies Solution. 4. Conclusion. 5.Bbliography.

ÜBERSICHT: 1. Enführung. 2. Die Europätsche Union. 2.1. Das Rechtssysten dey Gomenschaft 2.2. Das Prozessrech der Gemeinschaft 2.2.1. Der ordentlich Prozess. 2.2.1.1. Nichterullungshlage. 22.1.2. Unterlassungshlage. 2.2.1.3. Klage wegen dusservertaglicher Verbindlichket. 2.2.1.4. Nichtigheishlage. 2.2.15. Beamtemehtliche Klage.

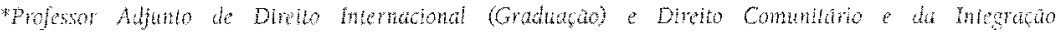

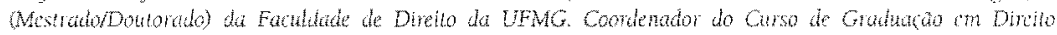

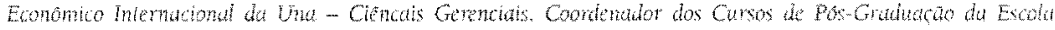

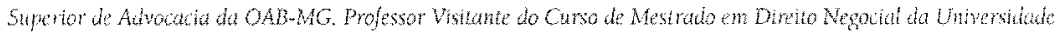
Fiadud de Lonthind.
} 
2.2.1.6. Entscheidung auf Yorlage. 2.2.2. Der ausserordentiche Prozess. 3. Der Mercosul. 3.1. Das Rechtssystem der Integration. 3.2. Lasung von Struthagen, 4.Schlussolgerung 5. Bibliographie.

RESUMO: O presente trabalho tem como objetvo abordar o Direto Comuntánio e da Integraçá, em seu aspecto processualistico, tomando como base o sistema de soluçäo de controverstas nos blocos de integração, com enfase para a experiencia comuntána e da integraça, aquela a partir da bem sucedida construção da União Européta e esta à luz dos Protocolos que regem a questao no ambito do Mercosul, procurando analisar os avanços a partir da comparacăo entre os sistemas.

ABSTRACT: The present work has as objective approaches the Community Right and of the Integration, in your processual aspect, taking as base the system of solution of controversies in the integration blochs, with emphasis for the community experience and of the integration, that starting from to good happened construction of the European Union and this to the light of the Protocols that they govern the subject th the ambit of Mercosul, trying to analyze the progresses starting from the comparison among the systems.

ZUSAMMENFASSUNG: Die vorliegende Arbeit beabsichtigt, das Gemeinschaftsrecht und die Integration unter threm prozessualistischen Gesichispunkt zu erörtern. Dabei nimmt sie als Grundlage das System der Streitlosung in den Integrationsblöchen, mit besonderer Berücksichtigung der Erfahrungen in der erfolgreichen Konstruktion der Europäischen Union und im Licht der Protokolle, die diese Frage im Bereich des Mercosul regeln; die Arbeit beabsichtigt, die Fortschrite anhand des Systemvergleichs zu untersuchen.

PALAVRAS-CHAVE: Diretio Comunitario. Dineito da Thtegraçăo. Solucha de Controversias. Mercosul. Integraçáa. Processo Comunitaño.

PALAVRAS-CMAVE: Integração. Brasil. Argentina. Mercosul. Comércio intemacional. 
KEY-WORDS: European Community law. Right of the Integration. Controversies Solution. Mercosul. Integration. Communitarian Process.

SCHLÜSSELWÖRTER: Recht der Europäischen Gemeinschaft. Integrationsrecht. Lösung von Streitfragen. Mercosul. Integration. der gemeinschaftsrechtiche Prozess.

\section{Introdução}

Para o correto entendimento da atualidade e importância destas formas de solução de controvérsias, torna-se imprescindível realizarmos uma rápida incursão no fenômeno da Nova Ordem Internacional e seus paradigmas: globalização e formação de Blocos Regionais de Integração.

Dentro do cenário da Nova Ordem Internacional', destaca-se, principalmente no plano econômico, o fenômeno da globalização. Este é extremamente complexo e abrangente, trazendo profundas transformações nos modos de produzir, nos espaços de atividade econômica, e, ao trazer reflexos para a própria sociedade, influencia também a atividade do Estado.

A globalização, dentro de sua amplitude, tem como principal aspecto um novo paradigma de organização da produção, que representa uma saída para a crise do modelo fordista, caracterizado basicamente pela profunda divisão e especialização do trabalho, grau bastante elevado de padronização, grande importância das economias de escala como fator de redução de custos da produção, forte tendência à verticalização e pouca preocupaçäo com a qualidade do produto por parte das empresas ${ }^{2}$. Essa crise se deu

\footnotetext{
1 Vide: SILVA, Roberto Luz. Direito internacional público. [Belo llorizonte]: Inédia, 1999. pg. 23 c sgs.

${ }^{2}$ A now alternativa apontada gira em torno de um sistema de produça mais lexivel, prevalecendo uma acentuada preocupaço com a qualidade, horizontalização da produção, polivalencia do trabalho, busca de trabathadores multifuncionais, terccirizacas, entre outros.
} 
principalmente pelo esgotamento dessa estratégia de produção e pela mudança nas formas de concorrência e seu acirramento em nivel mundial, buscando aumentar a competitividade.

Outro aspecto importante a ser ressaltado em relação à globalizaça é - lato das atividades economicas estarem atravessancio as fronteiras dos mercados nacionais e redesenhando seus espacos. Nos dias atuais, pode-se comprar uma determinada materia-prima em um cerlo pais, fabricar o produto em outro e comercializar em outro pais completamente diferente, através de um simples computador ligado à Internet. Esse quadro representa uma situacăo favorável para a atuaçäo das empresas transnacionais, que comerciam com vários Estados juntos.

Ja no plano politico, por sua vez, observa-se a crise" do Estado-Naço. No plano intemo, tais Estados tem fortes dificuldades em relacăo a capacidade de gerir os problemas sociais, o Estado de bem esta socia não consegue mais garantir a populaça as questoes sociais pelas quais era responsável. No plano extemo, observa-se uma forte mudança no que tange as relaços internacionais. Essa atual lase do Estado fica muito bem expressada na idéla de que o ele é atualmente grande demais para os pequenos problemas e pequeno demais para os grandes problemas.

A integraçäo dos blocos regionaís é lenômeno mais recente que a globalização, sendo estes, diametralmente oposios. A Comaça dos blocos regionais comeca a ocorrer no momento em que o multilateralismo solre $\mathrm{cm}$ enfracuecimento. Mas isto não significa ofim do processo de globalizaça. representa apenas a reaça de Blocose Estados-membros aos eleitos que ela acarreta

Assim, hä uma necessidade de profundas mudanças estruturais e uma das saidas vishumbradas para esse impasse e a integraço entre tais Estados,

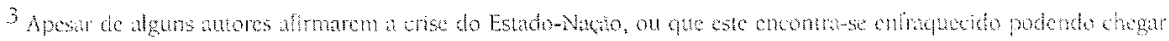

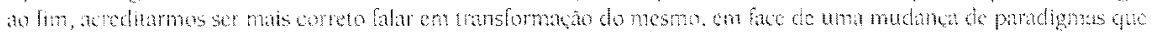

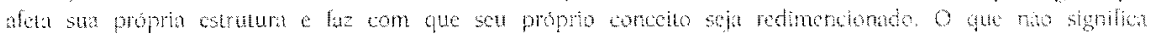

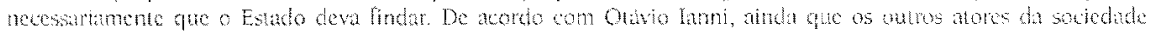

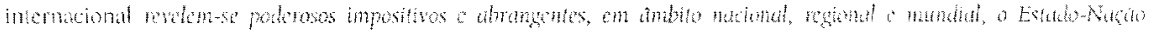

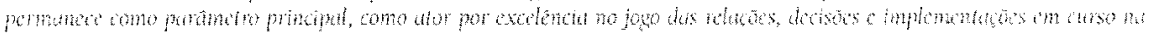

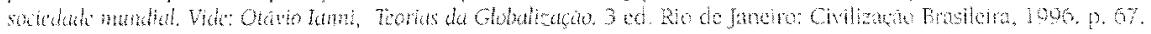


através da ampliação de mercados, que pode ser feita em vários níveis, dependendo de quanto e como se almeja aprofundar na integração.

Tem-se que a integração é um fenômeno complexo, pelo qual, através de acordos internacionais, os paises associados procuram potencializar suas forçás e combater conjuntamente suas debilidades, objetivando uma melhoria do bem estar interno, elevando, desta forma sua inserção na Sociedade Internacional. Numa imagem incompleta e simplificada, traduzse num sistema onde Estados Soberanos se associam como num pacto federativo, através da cessão ou renúncia de algumas de suas competências em lavor da Organização Internacional. Deutsch afirma ser a integração um relacionamento entre unidades, no qual elas são mutuamente interdependentes e em conjunto produzem propriedades de sistema que isoladamente não teriam, sendo tal sistema coeso na medida em que tiver condiçōes de enfrentar tensões e pressoes, assim como suportar desequilibrios e resistir a rupturas ${ }^{4}$. Laredo, citado por Pavan, a define como sendo um processo político de busca de uma mudança social voluntária, pelo qual, a partir da existência de problemas, interesses e objetivos comuns, as unidades nacionais se associam e adotam estratégias de ação conjunta para melhorar o staus dos países na região, de suas respectivas comunidades e sua inserção no sistema internacional estratificado ${ }^{5}$ diferenciando-se do processo de cooperaçăo, onde, além de não haver uma verticalização do processo, este se limita a determinadas áreas da pauta comercialo.

É dentro deste contexto que se percebe o latente e irreversivel processo de formação de blocos regionais, que assumem uma importância progressiva, cujo processo de integraçāo realiza-se em diferentes fases e abordagens conforme o interesses dos Estados. Assim, não há homogeneidade entre eles, podendo configurar desde uma zona de livre comércio até una união económica e monetária.

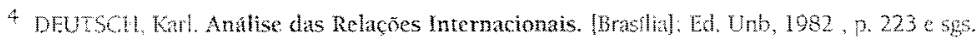

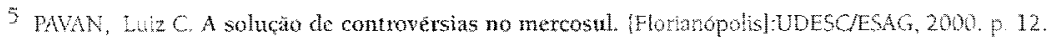

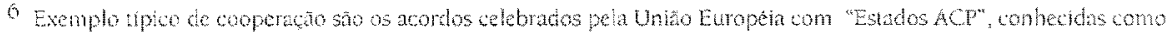
Convencôes de Kaunde e Lome.
} 
Podemos, desta forma, inferir que a globalização vem se realizando através da formação de blocos regionais de Estados, até como mecanismo de autodefesa contra esse processo, a exemplo da União Européia, do Acordo de Livre Comércio da América do Norte - Nafta, e do Mercado Comum do Sul - Mercosul, dentre outros, em cujo interior, sobretudo no âmbito da primeira, passou a desenvolver-se um novo tipo de Direito, o Direito Comunitário, que se coloca entre o Direito Interno e o Direito Internacional, ao promover a interaça entre os parceiros, dissolvendo preconceitos, diluindo falácias sobre estrangeiros, forasteiros ou alienigenas e favorecendo beneficios mútuos em lugar do exclusivismo de soluçōes autárquicas ${ }^{7}$.

Um Bloco Regional de Integração é, desta maneira, uma organização internacional formada por Estados localizados na mesma região, que iniciam uma integração econômica, levando a um processo de interpenetração dos seus Direitos internos e, gradualmente, à criação de um ordenamento juríclico gerado a partir dos acordos. O Bloco vai aos poucos adquirindo un caráter de unidade, podendo alcançar um nível tal de harmonizaçăo juspolítico-econômica, que configure uma união semifederativa de Estados.

O caminho para se alcançar a Integração é longo, podendo atingir diferentes graus e estägios de complexidade, de acordo com os interesses dos Estados-membros. Podemos ter, então, tipos distinlos de modelos de Integração ou estágios, em ordem crescente de um mesmo processo de complementaridade entre duas ou mais economias assim distribuidos:

- Área de Tarifas Preferenciais: representa a redução parcial das tarifas alfandegárias entre duas ou mais naçőes, que poderá eletivar-se de maneira diferenciada por setores ou produtos. A adoção deste tipo de Integração não implica outras politicas de ajuste para a sua viabilização, não havendo a necessidade de mudanças na política tarifária com relaçăo à terceiros paises.

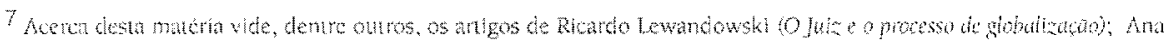

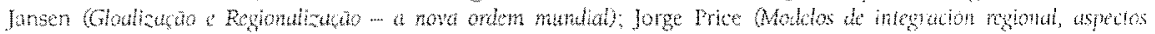
juthlice y watologicos.
} 
- Area de livre Comercio: nessa lase, temos a abolicajo total das larilas que incidem no comércio intra-área, que năo precisa ocorrer, necessariamente, para todos os produtos simultaneamente. O que geraimente ocorre é a eliminação para um certo número de produtos inicialmente e a gradual ampliaçăo da pauta de produtos a terem sua aliquota zerada no decorter do processo. Aqui também se adota o sistema tarifário independente com relaça a terceiros países. O aspecto fundamental nesta etapa de Integração é a unificação das nomas de controle de qualidade e de padronizacto de produtos, embrião de uma legislaçao especilica a ser implementada evolutivamente no Bloco Regional.

- Uniâo Adxaneira: neste estágio ocorre, a ém da anulaçào das tarifas allandegárias, uma unificaça da estrutura tarifäria relativa a terceiros paises, eviando-se o problema dos desvios de comércio e implicando um mínimo de harmonizaçio das políticas fiscal, monetária e cambial. Em geral, quando se chega a adotar uma Uniào Alfandegária, já se atingiu o estágio da aliquota zcro para todos os produtos do comércio intra-área. Com o estabelecimento de medidas conjuntas de barremas alfandegáras, em relaçăo aos paises que näo façam parte desta União, temos já presentes normas jurídicas comunitarias.

- Mercado Conum: este estágio inclui uma União Aduaneira. somada à live mobilidade dos fatores de produçao, desta foma, a én do livre comercio de insumos e de produtos finais, ocorte a lime locomocáo de bens de capital, recursos financeiros e de mäo-de-obra. Para tanto, há a necessidade da coorcenaça de varios aspectos da políica econômica dos paises signatários, como uma unificação do sistema previdenciáio e tributario, das leis trabalhistas etc., por outro lacio, a live mobilidade do fator capital, necessita a criação de una legislação comum em matéria de investimentos estrangeiros, royalties, e repatriamento de lucros, eletivando, desta forma, o Direito Comunitario.

- Unino Economica e Monetaria: tal estagio seria superado apenas pela fusão politica dos membros e a criação de um novo Estado. Nesta lase, atingir-se-ia tal grau de complementaridade do processo de Integração, que ter-se-ia uma unilicacăo das polnticas monetária, fiscal e cambial dos paises 
membros, criando-se uma moeda única e um Banco Central independente. Nessa etapa, como forma final do processo de Integração, teriamos a constituição de una Autoridade Supranacional, sustentada por nomas comunitárias eficazes, diretamente aplicáveis e com autoridade superior às nomas estatais internas, sendo suas decisoes acatadas e respeitadas pelos Estados-membros.

Os Blocos Regionais de Integraçăo, heterogêneos que são entre si; possuem caracteristicas variáveis de acordo com seus principais objetivos e propósitos. Assim, podem classificálos como: blocos económicos, comerciais e de produção.

Os Blocos Económicos săo os mais abrangentes, tendo como propósito a livre circulaça dos fatores de producão, apresentando uma perspectiva maior de integração entre seus membros. O melhor exemplo disso é a União Européia, organismo intemacional mais avançado no processo de integração, possuindo um mercado interno, política econòmica comum, relativas à agricultura, à indústria e a questōes regionais, além de uma política comercial comum. Dentro dessa classificação, insere-se também - Mercosul, o que pode ser constatado pelo art.1 do Tratado de Assunção ao prescrever que o mercado comum a ser consolidado implicaria na livre circulaçäo de bens, serviços e fatores produtivos entre os paises; o estabelecimento de uma tarila externa comum, além da adoção de uma política comercial comum em relação a terceiros; coordenação de políticas macroeconônicas e setoriais entre seus Estados-partes.

Já os Blocos Comerciais têm como objetivo uma livre circulaçăo de proctutos apenas em nivel tarifário e geralmente são constituidos por zonas de livre comércio. É o caso do Acordo de Livre Comércio da América do Norte - Nafta, composto pelo Canadá, os EUA e o México. Tal Acordo instituiu princípios que regulam o comércio e investimentos da região além de prever a eliminação de tarifas aduaneiras sobre bens e serviços num prazo de cinco anos, a partir de 10.01.1994. Seus objetivos são basicamente eliminar barreiras de comércio, promover condiçoes de concorrencia conjunta, proporcionar proteção adequada aos direitos de propriedade 
intelectual, entre outros. O processo de integracăo diz respeito apenas ao comercio, nảo se demonstrando a intencão de ampliá-lo a outros nuveis.

Por fim, o Bloco de Produção formado por um Estado central que fornece capital e tecnologia para a produça de insumos aos demais Estados periféricos. O retomo para aquele Estado é feito através da cobrança de royalties sobre o que foi produzido. Portanto, ha apenas uma espécte de troca entre capitaltecnologia e renda (royalties), nâo havendo possibilidade de integracăo, conforme as etapas supracitadas. Um exemplo desse tipo de bloco é o Comado pelo Japão e Tigres Asiáticos - Republica da Coréia, Formosa, China, Singapura, Indonésia, Malasia e Tailandia.

O processo de integração de Estados soberanos formando os chamados blocos regionais se funda em quatro bases que se interrelacionam: a base econômica, a base política, a base social e a base jurídica. Assim, pode-se afirmar que processo de integracăo busca a maximizacão regional de todos os Catores econômicos. Esse objetivo só pode ser. conquistado atraves da convergéncia de uma firme vontade politica entre os governos regionals. Para tanto, os governos necessitam do respaldo interno, ou seja, do apoio majoritario dos seus nacionais, sob pena do processo de integracão se tomar legitimo e, via de regra, mai sucedido. Una vez estabelecidos os objetivos socio-economicos a serem alcançados com a mecanica da integraça, cujo processo seja movido por uma lonte determinação politica dos Estados, amparada intemamente pelos seus nacionais, tonna-se indispensavel a elaboração de um arcabouco junidicoinstitucional que seja capaz de materializar e de efetvar o processo de integraçào, tornando-o auto-sustentavel. Essa ordem juridica de alcance supranacional regionalizado, e que dá instrumentalidade ao processo de integração, constitui um Direito novo que apresenta caracteristicas originais.

Nesse ponto, há que se distinguir o Direito da Integraçăo do Direito Comunitário. O primeiro é um desdobramento do Direito Internacional Público clássico, ou seja, decone de tratados intemacionais entre Eistados soberanos que, por diversas razóes, criam zonas econômicas privilegiadas com maior ou menor vinculação entre os seus integrantes. Esse Direito é 
encontrado nas fases iniciais e mesmo intermediárias dos processos de integração econômica regional. Nesse contexto, o Direito da Integração não tem autonomia positivo-epistemológica, eis que parte do próprio Direito Internacional Público.

O Direito Comunitário, por sua vez, só se faz presente no processo de integração acompanhado da delegação de soberania e da formação de uma esfera político-jurídica supranacional. Embora remonte a um Direito da Integração, o Direito Comunitário pressupoe um estágio bastante avançado de interação economica, política, social e jurídica entre Estados soberanos. A certo nivel de interaça regional, o exercicio da soberania passa a ser feito, necessariamente, de forma compartilhada entre todos os Estados que compöem a comunidade e entre a comunidade e os seus Estados-membros. Ocorre, nesse caso, um fenômeno político que se pode chamar de supranacionalidade, ou seja, a existência de uma esfera político-jurídica encontrada na sociedade internacional que, convivendo com todos os Estados soberanos, se caracteriza pelo agrupamento de Estados, que embora soberanos, estão vinculados, entre si, por uma autolimitação, delegação e compartilhamento de suas soberanias com a primazia de um poder politico regional e coletivo, de natureza estatal, mas desprovido de autoconstituição.

A partir desta rápida análise do fenómeno da globalização e seu reflexo na formação de Blocos regionais de Integração, retomamos a análise do Direito Processual Comunitário e da Integração, tendo como alicerce o processo comunitário europeu que, apesar de tratar de uma realidade muito majs complexa, apresenta-se como paradigma para a construção do sistema integracionista de solução de controvérsias, já que nos lega um extenso rol de solucoes criativas que podem ser perfeitamente aproveitadas pelo Mercosul.

Sabe-se que, pelo que o Mercosul apresenta em sua estrutura atual, resulta claro que não existe um compromisso formal de integraça mais profunda, havendo indicações que isto só vai acontecer na etapa de transição da união aduaneira para o mercado comum, ponto de chegada eleito. E disto se fala porque até o momento presente o Mercosul, foi administrado 
consensualmente por órgãos de natureza intergovernamental, ligados às burocracias das Chancelarias respectivas, dos Ministérios da Economia e Bancos Centrais, o que gera notorias dificuldades". Visto desta forma, a afimaça do Mercosul como bloco econômico de integração, estaria sujeito as mais variadas criticas, todavia, como ressalta Pavan, citando Salgado, não existem modelos teminados de integracão e muito menos uma receita acabada, que possa ser seguida indistmtamente por todos os países, necessitando cada um deles das adaptacoes à sua própria realidade".

\section{Uniảo Européia}

Os principais esforços no sentido da Integração Européia começaram com o Tratado de Dunquerque, de 1947, assinado entre a França e Reino Unido, de aliança e assistencia reciproca contra qualquer possivel nova agressăo alema, mas que incluia, igualmente, promessa de copperaço no interesse geral da prosperidade e da segurança econômica dos dois paises. Seguiram-se, o Congresso de Haia, realizado entre 7 a 10 de maio de 1947 , convocado pelo Comite Internacional de Coordenaça dos Movimentos para a Unidade Européia para discutir sobre organizaçoes movimentos de unificacão surgidos na Europa do pós-guerra ${ }^{\circ}$, o primeiro anúncio do Plano Marshall, em junho de 1947", a formaça, em julho do mesmo ano, do

\footnotetext{
8 PAVAN, Luiz C. A solucăo de controversias no mercosul. [Florianopolisl:LDESC/ESAG, 2000 p. 13. 9 p. 14 .

10 Dummé o congresso que contou com a presenca de ollocentas personatidades duas tendencias flaram ritidamente

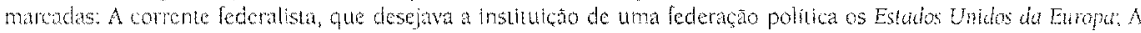
conente progmatica que acteditava que o objetivo último da unificaçäo da Europa deveria ser abançado progressumente atraes de una contetaça ada vez mas esteja entre os Estalos soberdnos. Os congressistas, apesan

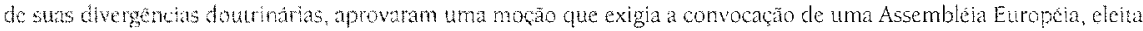

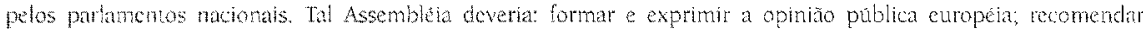
medicas polnchs e econombas adequadas do encaminhamento da unidnde europera; examinar os problemas de matura tonstitucional que a chacho de uma Federaço ou Confederaça suscitaria, propor a criaca de um Tribunal

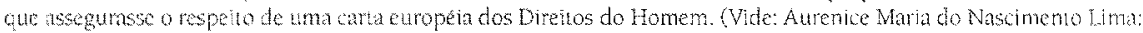

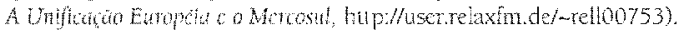

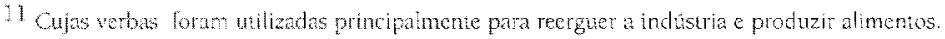


Comitè de Cooperação Económica Européia, e a assinatura da Convenção sobre Cooperação Economica Européia, em abril de 1948. Em maio de 1949, foi firmado o estatuto do Conselho da Europa, prevendo a formaça de uma assembléia consultiva, o chamado Parlamento Europeu. Em 1950 fot criada a Uniào Européia de Pagamentos - UEP, que visava facilitar o comércio e as transaçoes financeiras multilaterais na area do comércio europeu.

Pelo Tratado de Paris foi instituida, em 18 de abril de 1951, a Comunidade Européia do Carväo e do Aço - CECA ${ }^{2}$, entre Alemanha, Bélgica, França, Itália, Luxemburgo e Países Baixos. Um projeto de Tratado, visando a criaçào de uma Comunidade Européia, inicialmente denominada Comunidade Política Européia, elaborado em 1953, não chegou a ser ratilicado. Todavia, em marco de 1957, os Ministros das Relaçoes Exteriores dos Estados membros da CECA, firmaram o Tratado de Roma, para a criação de uma Comunidade Econômica Européia, e o estabelecimento gradual de um Mercado único Europeu, com o eventual livre trânsito de mercadorias, pessoas e serviços entre $\mathrm{s}^{3}$. No decorrer dos anos, nove novos paises se integraram à União', que passou a contrapor-se ao Bloco norte-americano e soviético, posteriomente substituido pelo astático. Já na década de 70 , a União Européia, que havia instalado-se como um mercado comum, começou a considerar um aprofundamento da Integração, a nível político-econômico. O complexo processo de Unificação veio desenrolando-se, ao longo dos $\operatorname{anos}^{13}$ e, acelerando-se com a implantação do Tratado de Maastricht ${ }^{16}$ e,

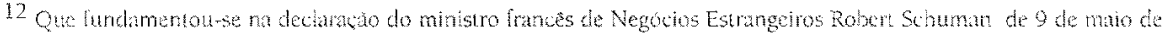

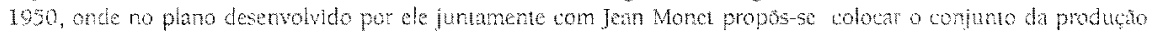

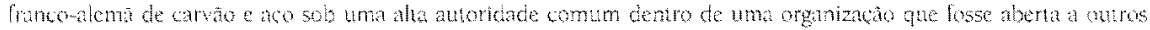
Estados curopeus.

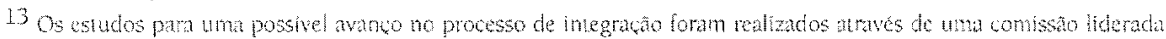
pelo ministro belga de Negocios Estrangeres Spak. En 1956 aquela Conissä apresenta o resulado de seus estudos que servit de lundmeito para as negotacoes dos tratalos que fundaram a Comunidude Fconomica Europeia CEE E 3. Comunidade Européia de Energin Alomica - EuRATOM. Os Tratados foram assinados em 25 de mareo de 1957 c

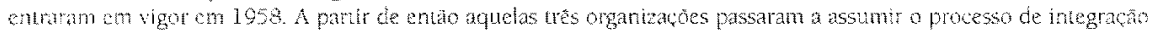
curopitin.

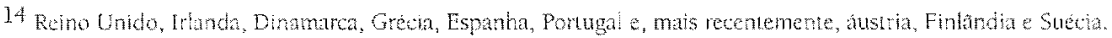

15 Em 1986, o Ato unico Europeu previu a live circulaço de pessons, meradorias, servicos e capitás, a partir de 1.1,1993. cimstium uma serte de nowas politicas.

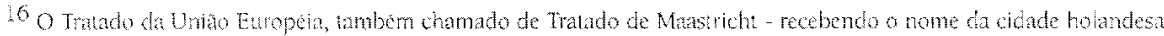
onde foi assinado em 7 de fevereiro de 1992, modificou amplamente os twados consiuuves vigentes, apesar de, na

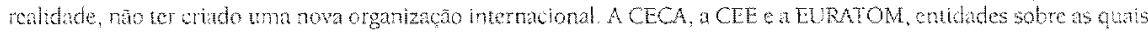


mais recentemente, com o Tratado de Amsterdam, de 2 de outubro de 1997 , que alterou substancialmente o Tratado de Maastricht no tocante:

1. a promoção do progresso econômico e social e de um elevado nível de emprego e realização de um desenvolvimento equilibrado e sustentavel, nomeadamente mediante a criaçăo de um espaço sem fronteiras internas, o reforço da coesão econômica e social e o estabelecimento de uma união económica e monetária, que incluirá, a prazo, a adoção de uma moeda única;

2. a alimação da sua identidade na cena internacional, nomeadamente através da execução de uma política externa e de segurança comum, que inclua a definição gradual de uma política de defesa comum, que poderá conduzir a uma defesa comum;

3. ao reforco da defesa dos direitos e dos interesses dos nacionais dos seus EstadosMembros, mediante a instituiçào de uma cidadania da União;

4. a manutenção e o desenvolvimento da Uniăo enquanto espaço de liberdade, de segurança e de justiça, em que seja assegurada a livre circulação de pessoas, em conjugaça com medidas adequadas em matéria de controles na ronteira externa, asilo e imigração, bem como de prevenção e combate à criminalidade;

5. a manutençăo da integralidade do acervo comunitário e o seu desenvolvimento, a fim de analisar em que medida pode ser necessário rever as políticas e formas de cooperação instituídas, com o objetivo de garantir a eficàcia dos mecanismos e das Instituições da Comunidade.

Segundo Márcio Luís Oliveira, citado por Silva ${ }^{17}$, o que se pode constatar é que na Uniào Européia a lonte de todo o poder comunitário está na soberania originária de cada um dos seus Estados-membros. Os poderes

se assenta a Unio Européd, wonservan separdamente seus caracteres de sujelos de Direito Intenthonal. Tendo

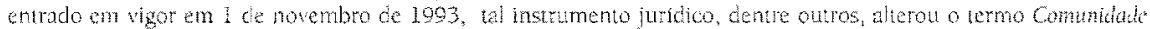

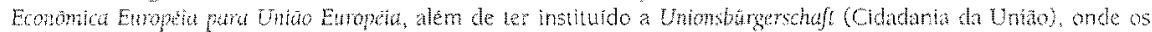

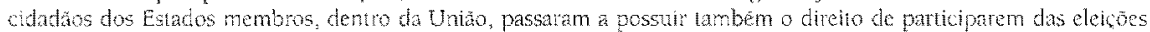
munkipais a dos membros do partanento Europeu. no lugar de seu domicilo. independentemente de sta

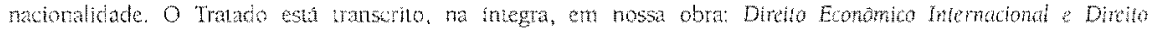
Comunitátio

17 SILVA, Robeno luiz. Direilo Commitario e da Integração. PPono Alegrel. Sinese. p. 41. 
da Uniāo são derivados da soberania originária dos Estados que a integram, embora a ordem juridica comunitaria tenha primazia sobre as ordens juridicas nacionais. O poder constituinte comunitärio não se concentra na União, mas nos Estados-membros que o exercem coletivamente. Como sustentou Schuman ${ }^{18}$, a supranacionalidade situa-se a meio caminho entre, por um lado, o individualismo internacional que considera intangivel a soberania nacional e não aceita outras limitaçóes desta soberania que não as resultantes de obrigaçoes consensuais, ocasionais e revogaveis; e, por outro lado, a federação de Estados subordinados a um super-Estado dotado de soberania territorial propria.

No caso específico da União Européia, o principio da subsidiariedade $^{19}$ - apesar de controvertido e vago em seu contéudo, e portanto dependente de melhor interpretação e ou regulamentação colabora na sustentabilidade do exercício de uma soberania compartilhada entre os Estados-membros e entre estes e a própria União, como informa Branco:

(..) as nacoes dos Estados-membros năo perdem, mas apenas preservam seus direitos soberanos, ficando como meras partes limitadas em certas áreas. Essa diretriz é afimada e tem fulcro no princípio da subsidiariedade, estabetecido no preâmbulo do Tratado da União Européia (Acordo de Maastricht). Esse dispositivo declara que no processo de criação de uma uniāo mais proxima entre as pessoas da Europa, as decisóes serāo tomadas 'o mais próximo possivel dos cidadãos de acordo com o principio da subsidiariedade’. Estabelecelt-se, também, no paragrafo final do artigo B da União Européia, que, realizando-se os objetivos da União,o principio da subsidiariedade (definido pelo Tratado de Roma, no segundo parágrafo do artigo 3b) será respeitado. Esse principio tem por finalidade determinar una divisao entre os atuais poderes da Comunidade e os poderes

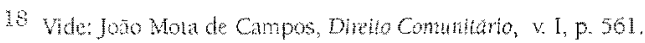

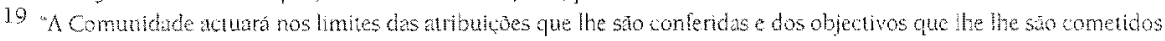

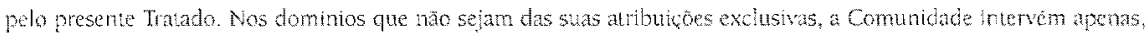

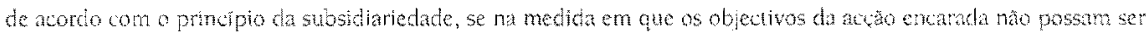

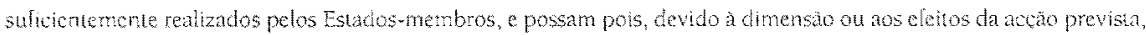

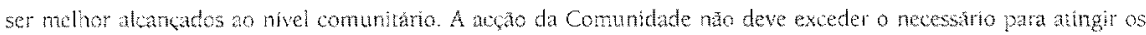

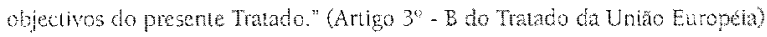


residuais dos Estados-membros. Estes perdem o direito de vetar as aços comunitanas e sentem uma necessidade de inserir uma clausula cxpressa de protecano. O principio da subsidiariedade constitu, para os Estados-membros, um mecanismo judicial obrigatorio de autodefesa contra o que se percebe como un risco do uso excessivo dos poderes comunitarios, garantindo o direito dos seus proprios poderes residuats em arcas nä cobertas pelas acoes comunitarias. A subsidiariedade, portanto, é um conceito atil que vem responder as criticas de que esta Comunidade pudesse ser excessivamente centralizadora, obliterando a identidade nacional. Nesse sentido, a essencia da subsidiariedade e proteger os diveitos dos Estados-membros contra a invasäo de Bruxelas nos assuntos que efelvamente näo atinjam a esfera comunitaria, servindo como um substiuto de protecáo politica dos poderes residuais dos Estados-membros, que assim mantém sua independência $e$ autonomia.

Nas palavias de Joa Quadros ${ }^{20}$, principio da subsidiariedade, como garantidor da soberania compartihada, é reforçado pelos princípios da proporcionalidade $^{21}$, da solidariedade 22 da coesäo econômica e social ${ }^{23}$. A interpretaço sistemica e teleologica destes quatro principios pelas instituiçoes comunitánas, em especial no processo legislativo comunitário e na jurisdiça comunitária, tornará possivei o alargamento das competencias

20 In: En Torno th fevisto do Tralado da Una Europen, 1997, p. 239-240.

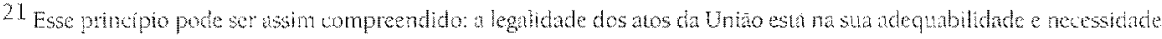

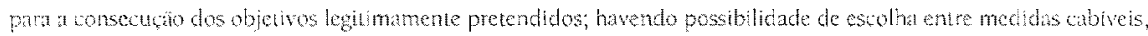

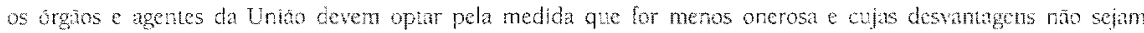

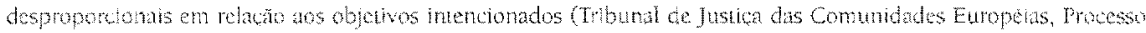

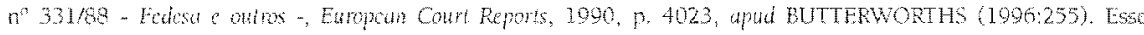

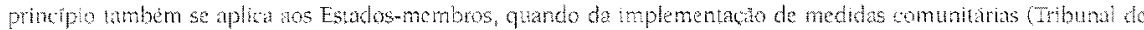

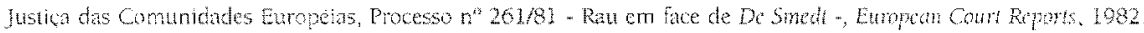
p. 3961 , apui BUTTEWWORTL (1996255).

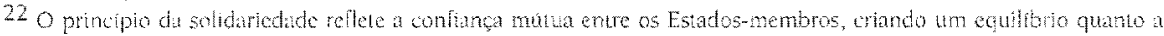
direitos obrigaces ben como vinulands os Estadosmembros a Unito, dando-ite preferenda e manchdo sua

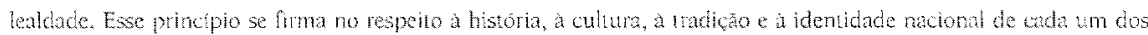

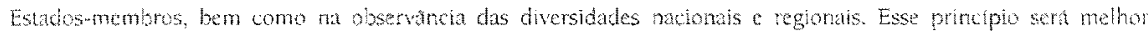
aborato an andise da ordem jurdica comuntaria.

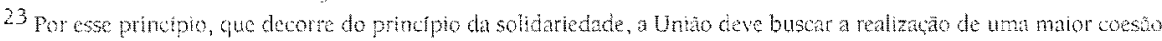

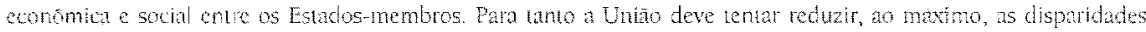

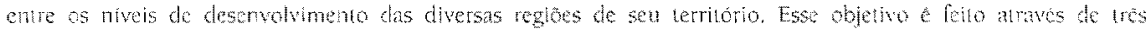

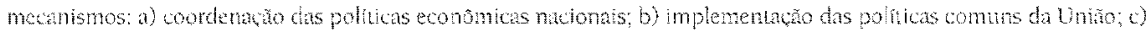
aprimoramento do matudo comum incrom. 
da União Européia sem a ocorrência de uma centralização desregrada e sem anular as soberanias nacionais. $O$ aprimoramento da integração européia se sustenta exatamente na estruturaçăo e na efetivaçăo de um mecanismo juridico que seja capaz de manter o equilíbrio do poder politico dos seus Estados-membros com o resultado final da delegação de competencias para a União.

\subsection{O Sistema Juridico Comunitário}

Como observou-se, a construção da Uniāo Européia é um projeto que se desenvolve já há muitos anos e paradoxalmente aos projetos de integração latino-americanos, aqueles lançaram no tratados fundamentais, basicamente todos os principios e instituiçöes pelos quais a Organizaça Internacional operaria, aperfeicoando-os ao longo do tempo.

Conscientes da envergadura do projeto e da necessidade de seu desenvolvimento em bases estruturalistas, os autores dos Tratados de Paris $e$ de Roma criaram uma instituição dotada dos órgãos fundamentais ao seu funcionamento, aperfeiçoada no Ato ünico Furopeu e, mais recentemente, nos Tratados de Maastricht e de Amsterdam.

Desta forma, a União Européia caracteriza-se por um sistema institucional único no seu genero, o qual a distingue das organizaçoes internacionais clássicas. Ao subscreverem os Tratados de Paris e Roma, os Estados-membros passaram a autorizar diversos atos de delegação de soberania em beneficio de orgãos de natureza supranacional, os quais representam, simultaneamente, os interesses nacionais e comunitários, estando interligados por relaçoes de complementaridade de que decorre o processo de decisão.

Estes órgãos formam a estrutura institucional da Uniäo Européia, tendo, entre outras funçóes, a de criar o Direito Comunitário, agi. soberanamente nos limites estabelecidos pelos tratados modificando, muitas vezes, realidades da vida cotidiana européia com plena autonomia.

- Na União Européia, o processo de decisão associa mais especificamente a Comissão das Comunidades Européias, que elabora 
propostas e executa as açoes adotadas; o Parlamento Europeu, que se pronuncia sobre essas propostas; e, o Conselho, que adota a decisão final. Tribunal de Justiça e o Tribunal de Primeira Instância garantèm o respeito ao Direito Comunitário. O Tribunal de Contas controla a gestão financeira da União. O Comitê Econômico e Social e o Comitê Consultivo CECA dispõem de uma competência consultiva. Atuam, ainda, o Banco Europeu de Investimentos, como instituição financeira, o Comitê das Regiões, como órgão de implementação das políticas comunitárias junto às autoridades regionais e locais, e o Provedor de Justiça (ombudsman), como órgão de delesa do cidadão europeu frente aos atos de má administraçăo por parte dos organismos ou instituiçóes comunitárias e o Instituto Monetánio Europeu, como condutor do processo de unificação monetária

Ao Tribunal de Justiça das Comunidades Européias reconhece-se competência consultiva e contenciosa, exercida esta tanto nos recursos diretos, inclusive os originários do Tribunal de Primeira Instância, em matéria de direito, quanto na chamada questão prejudicial, incumbindo-lhe, ainda, agir nos conflitos entre:

- os Estados-Membros,

- da União Européia contra os Estados-Membros,

- orgáos comunitários,

- orgão comunitário e particulares.

Já ao Tribunal de Primeira Instancia, incumbe servir de instância recursal aos funcionários da União Européia e solucionar litigios entre particulares nas áreas de:

- concorrência,

- medidas antidumping e

- indenizaçōes.

Os órgãos judiciais nacionais também participam do sistema comunitário, por via reflexa, pois na medida em que é gerado pelos organismos próprios, o Direito Comunitário incorpora-se ao ordenamento juridico interno de cada Estados-Membros, num movimento de 
harmonização. Ao longo da consolidação deste experimento de integração, a construção juridica comunitária foi erigida a partir de direitos fundamentais, sedimentados pelo principio de que as regras commitárias teriam aplicação direta, sem necessidade de ato prévio de incorporação e prevaleceriam sobre a norma interna de cada pais.

Assim, os regulamentos $e$ as diretivas dos órgãos comunitários imprimiram rumo ao processo, enquanto que o Tribunal de Justiça das Comunidades Européias, solucionando os conflitos, foi consolidando o Direito Comunitário, a partir da interpretação jurisprudencial dos tratados fundamentais e seu direito derivado.

A pirâmide deste sistema jurídico está assim conformada:

- Direito comunitário primário, oriundo dos Tratados originais,

- Direito comunitário derivado, nascido a partir dos atos juridicos comunitários, tendo fundamento nos regulamentos, diretivas, decisōes (obrigatórios), recomendacôes e pareceres (orientativos),

- Acordos internacionais anteriores e posteriores à constituição das Comunidades,

- Convençóes entre Estados-Membros,

- Princípios Gerais do Direito,

- Jurisprudência, e o

- Direito supletivo, para preencher lacunas baseando-se no direito internacional público e direito interno.

\subsection{O Regime Processual Comunitário}

O regime processual dos Tribunais Comunitários encontra-se previsto não só em dispositivos dos Tratados institutivos da Comunidade Européia do Carvão e do Aco - CECA, da Comunidade Econòmica Européia - CEE, e da Comunidade Européia da Energia Atômica - EURATOM, mas, ainda nos Protocolos relativos ao Estatuto do TJCE e, principalmente, no Regulamento de Processo do Tribunal de Justiça das Comunidades Européias, de 19 de 
junho de 1991, e Regulamento de Processo do Tribunal de Primeira Instância, de 2 de maio de 1991. Divide-se em Processo Comum, que engloba as açôes por Descumprimento, por Omissão e de Responsabilidade Extracontratual, os Recursos de Anulaçao e de Funcionários, e o Reenvio Prejudicial, e Processo Especial.

\subsubsection{Processo Comum}

Tal procedimento, inspirando-se nas normas processuais aplicáveis pelos órgăos jurisdicionais nacionais, encontra-se subordinado aos princípios fundamentais do processo que passamos a expor:

- principio inquisitório - através dele caberá aos Tribunais a iniciativa de coordenar e efetivar todas as medidas de instrução, cabendo às partes: indicar, impugnar e inquirir testemunhas; e impugnar peritos;

- principio do contraditório - por ele, qualquer das partes poderá tomar conhecimento das razóes e meios de prova produzidos pela parte contrária;

- principio da publicidade - tanto a audiencia quanto a leitura da sentença serão, via de regra, püblicas.

O regime linguistico do processo é escolhido pelo demandante, ressalvadas, Lodavia, as seguintes excecóes: se o demandado for um Estadomembro ou pessoa singular/coletiva deste Estado-membro, a língua de processo é a lingua oficial desse Estado ${ }^{24}$; e, a pedido de ambas as partes, poderá utilizar-se um terceiro idioma ${ }^{25}$. A redução dos idiomas oficiais da Uniào vem sendo apontada, por alguns setores, como indispensável para o seu desenvolvimento futuro, no contexto da eficácia institucional e da viabilidade do sistema em face de novos alargamentos, apesar de reconhecerse que a utilização da língua nacional é um fator que garante a transparencia processual, fundamental à segurança jurídica. No Reenvio Prejudicial, utilizarse-á o idioma do órgäo judiciário nacional que tenha recorrido ao Tribunal.

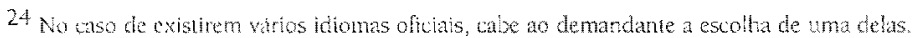

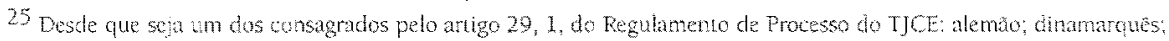
espanhol; rances; arego; ingles; irindes; ilatiano; neerlandes; e, porugues.
} 
Qualquer peça processual ou documento juntado em língua diferente da do processo deverá ser oficialmente traduzida ${ }^{26}$. Testemunhas, peritos, juizes e advogados-gerais, poderão manifestar-se numa língua diferente da do processo, providenciando-se a sua tradução para esta.

A representação das partes no processo é obrigatória, podendo a mesma ser realizada por um agente, nomeado pelos Estados ou Instituiçóes Comunitárias especialmente para tal fim ${ }^{27}$, ou por um advogado, no caso de particulares.

O processo perante o Tribunal é gratuito. Há o pagamento apenas das despesas processudi ${ }^{28}$, sendo estas recuperáveis pela parte vencedora, desde que a tenha requerido durante a lase escrita do processo. Se uma parte encontrar-se na impossibilidade de fazer face, total ou parcialmente, às despesas do processo poderá, a qualquer tempo, requerer o beneficio da assistência judiciária. Tal pedido deverá ser acompanhado de todos os elementos que provem que o requerido se encontra em situação de necessidade, nomeadamente de um atestado da autoridade competente que comprove a falta de condiçoes financeiras ${ }^{20}$. Tal beneficio poderá ser retirado, caso as condiçoes que determinaram a sua concessão tenham se modificado, no transcurso do processo.

Os prazos processuais são os seguintes:

- duas semanas - para interpor recurso contra indeferimento de un pedido junto ao Tribunal de Primeira Instância;

- um més - para interpor processo contra atos da Alta Autoridade CECA ou para contestar uma petiçăo introdutória de instância;

- dois meses - para interpor processo contra atos da Comissão ou do Conselho CEE/EURATOM, para se apresentar memorandos nos processos de

\footnotetext{
26 No aso de pecas edocumentos volumoses, pode-se linitar as traduçes a extras.

27 Comprovando a sua qualidade por uma credcncat extida pelo Estadofnstituicio. podendo os mesmos serem assibitos por um consetheiro ou axlsogndo

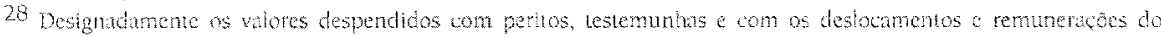
agente, consulor ou adwogkdo.

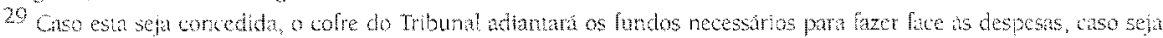
negrata, o despacto e suscetivel de recurso.
} 
Reenvio Prejudicial, bem como para interpor recurso contra decisão do Tribunal de Primeira Instância;

- cinco anos - para instaurar uma Ação de Responsabilidade Extracontratual da União ${ }^{30}$.

Tais prazos säo calculados a partir do dia seguinte ao recebimento da notificação, ou a partir do décimo quinto dia seguinte ao da publicação do ato no Jornal Oficial, incluindo-se feriados oficiais ${ }^{31}$, sábados e domingos. Se o prazo encerrar-se num sábado, domingo ou feriado, o seu termo transferese para o primeiro dia útil seguinte. A estes prazos é acrescida uma dilatação, em função la distância para com a sede dos Tribunais, em Luxemburgo, que é a seguinte: dois dias para a Bélgica; seis dias para a Alemanha, França e Países Baixos; dez dias para o restante dos Estados-membros; duas semanas para outros Estados e territórios europeus; três semanas para as regiões autônomas dos Açores e da Ilha da Madeira; e, um mês para os Estados, departamentos e territórios de outros continentes.

O Processo comporta, basicamente, três fases: escrita, de instrução e oral.

A fase escrita, também conhecida como articulados, tem início com a elaboração de uma petição introdutória de instância, encaminhada à Secretaria do Tribunal e que deverá conter:

1. nome e residência do demandante; a identificação da parte contra a qual o pedido é apresentado;

2. pedido do demandante;

3. as provas oferecidas;

4. domicílio e a pessoa, na cidade de Luxemburgo, autorizados a receber todas as notificações;

5. e, o documento comprobatório de que o signatário, no caso de advogado, está autorizado a exercer a advocacia nos tribunais de qualquer dos Estados-membros ${ }^{32}$.

30 Contados a partir da ocorrencia do fato que tenha dado origem à lesão.

31 Cuja lista, elaborada pelo TJCE, é publicada no Jornal Oficial da Uniāo Européia.

32 Ao advogado só será obrigatório a juntada de procuracaao que o habilite a representar a parte no litigio, caso se tratc de pessoa juridica. No caso de pessoa fisica, tal so será necessário se sua representação for contestada. 
Se a petição não preencher tais requisitos, o secretário do Tribunal fixa, para o demandante, um prazo razoável para a regularizar.

A pós a apresentação da petição na Secretaria, o pedido è inscrito no Registro e posteriormente divulgado no Jornal Oficial das Comunidades Européias, onde é especificado seus fundamentos e os pedidos do demandante. O Presidente do Tribunal distribui o processo a uma das Seçöes, para as eventuais medidas de instruçäo, e designa, no âmbito dessa, o juiz-relator ${ }^{33}$.

A petição é, então, notificada ao demandado que deverá no prazo de um mês, contado a partir da notificação, apresentar uma contestação ou resposta, que conterá:

1. nome e domicilio do demandado;

2. os argumentos de fato e de direito invocados;

3. as conclusões do demandado;

4. e, as provas oferecidas.

A contestação poderá ser passivel de um réplica do demandante e de uma tréplica do demandado ${ }^{34}$.

Após a apresentação da tréplica, o Presidente fixa a data em que o juiz-relator deverá apresentar ao Tribunal um relatório preliminar, que deverá conter propostas acerca da adoção de diligências de instrução ou outras medidas preparatórias ${ }^{35}$. O Tribunal, então, decidirá ou pelo início da fase de instrução, ou da fase oral.

Caso opte pela fase de instrução o Tribunal, ouvido o advogado-geral, determina, por despacho, as medidas que julgar conveniente.

As diligências de instrução, realizadas pelo próprio Tribunal, com a presença do advogado-geral, compreendem:

a.comparecimento pessoal das partes;

b. a prestação de informações e apresentação de documentos;

\footnotetext{
33 Nos proessos distribuidos às Secós, os poderes do Presidente do Tribunal sãu cxercidos pelo Presidene da seça. 34 As datas em que essas pecas devam ser apresentadas săo fixadas peto Presidente.

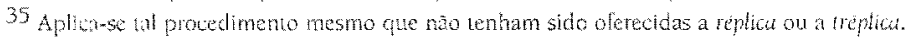


c.prova testemunhal;

d. prova pericial; e

e. inspecão.

Depois de encerradas as diligências de instruçăo, poderá ser concedido as partes um prazo para a apresentacáo de alegaçes escritas, sendo a lase ond intiada apos o fim de tal. prazo. O juiz-relator resume, num relatório para audiencia, os fatos alegados e a argumentaça desenvolvida pelas partes e, se for o caso, pelos outros intervenientes. Tal relatóno será divulgado, no idioma do processo, durante a audiência.

A fase oral é realizada em audiencia e tera inicio com os debates, dirigidos pelo Presidente, podendo este, no seu curso, fazer perguntas aos agentes, consultores ou advogados das partes ${ }^{3}$. Esta se encerara com a apresentacăo das conclusoes do advogado-geral, nas quais analisa detalhadamente a matéria de lato e, sobretudo, os aspectos jundicos do litiglo e propõe ao Tribunal a solução que the parece mais adequada ao problema. O Sectetáio, entăo, lavraráma ata da audencia, assinada por ele e pelo Presidente, tendo início a lase de decisá do processo, onde os juízes deliberam com base num projeto de acorda elaborado pelo juz relator.

Sobre questöes processuais incidem os despachos, que podem ser proferidos após um debate oral e que năo săo, necessariamente, fundamentados, já a decisao fund do Tribunal é proferida em Acónâo que contera:

a. a indicaça de que é proferido pelo Tribunal;

b. a data em que loi proferido:

c.os nomes do Presidente e dos juizes que participaram da deliberacão; o nome do adrogado-geral;

d. nome do secretário:

e.a indicaca das partes;

f. os nomes dos agentes, consultores ou advogados das partes;

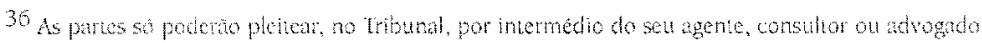


g. pedido das partes; a mençăo de que o advogado-geral fol ouvido;

h. a exposição sumária dos fatos;

i. os fundamentos da decisão; e

j. o dispositivo, incluindo a decisão quanto às despesas.

O Acórdäo é pronunciado em audiência pública, tendo força obrigatória desde o dia em que é proferido, sendo, por fim, publicado na Coletânea de Jurisprudência do Tribunal ${ }^{37}$. O Acórdão tem caráter definitivo, só sendo passível de retificaçáo quanto a erros de escrita ou de cálculo ${ }^{33}$.

\subsubsection{Acäo por Descumprimento}

A ser proposta pela Comissão ou por um Estado-membro da Uniăo Européia quando considerarem que um outro Estado-membro faltou a uma das obrigaçoes que the incumbem no quadro da ordem juridica comunitatia, como estipulado nos artigos 169,219 e 227 do Tratado de Roma:

Art. 169 - Se a Comissão considerar que um Estado-membro näo cumpriu qualquer das obrigaçoes que the incumbem por força do presente Tratado, formulara um parecer fundamentado sobre o assunto, apos ter dado a esse Estado oportunidade de apresentar as suas observaçoes.

Se o Estado em causa näo proceder em conformidade com este parecer no prazo fixado pela Comissäo, esta poderá recorrer ao Tribunal de Justica.

Art. 219 - Os Estados-membros comprometem-se a não submeter qualquer diferendo relativo à interpretaça ou aplicação do presente Tratado a um modo de resolução diverso dos que nele estão previstos.

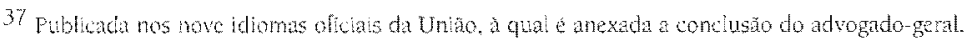

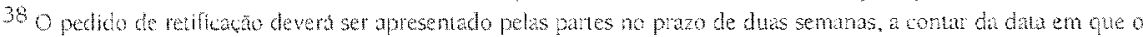
Acortato loi prolerido. 
Art. 227 - Qualquer Estado-membro pode recorrer ao Tribunal de Justiça, se considerar que outro Estado-membro näo cumpriu qualquer das obrigaçoes que the incumbem (...)

A noção de descumprimento inclui não só a inobservância do Direito Comunitário Primário e Derivado, mas ainda dos princípios essenciais da ordem juridica comunitania ${ }^{30}$ e das proprias decisóes do Tribunal de Justiça das Comunidades Européias.

Em sua defesa, o Estado geralmente invoca:

- imputabilidade da violação a um órgão estatal externo;

- situaçoes decorrentes da ordem interna incompativeis com a observância do Direito Comunitário;

- inexistência de intenção culposa elou ausência de prejuizo;

- cláusula de salvaguarda, estado de necessidade, falta cometida pela autoridade comunitária;

- causas justificativas admitidas em Direito Internacional Público;

- diliculdades administrativas ou outras na aplicação do Direito Comunitârio;

- oposição de norma comunitária a certos interesses nacionais;

- falta de uso das disposições contrárias ao Direito Comunitário ou do próprio Direito Comunitário;

- irregularidades na fase preliminar do processo elou demora na instauracăo do processo.

O Acórdão do TJCE tem o efeito de obrigar o Estado a adotar as medidas ou disposiçoes internas necessárias para a boa aplicação do Direito Comunitário, gerando a inaplicabilidade de pleno direito do ato estatal, uma vez que as autoridades ficam impedidas de aplicar a regra nacionat ${ }^{\text {to }}$.

Apesar de näo poderem constituir-se pólo ativo na presente açäo, aos particulares getamse a possibilidade de não mais acatar as nomas internas incompativeis com o Direito Comunitário, invocando tais dispositivos em

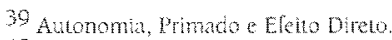

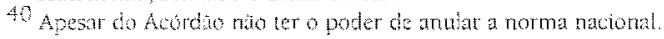


sua defesa nos tribunais nacionais, além da perda ex tunc da eficácia da norma interna e de reembolso, caso o ato nacional gere um prejuízo real.

\subsubsection{Ação por Omissão}

Da mesma forma que os Estados-membros da União Européia estarão sujeitos a processo perante o TJCE caso não cumpram as normas comunitárias, os órgãos comunitários, notadamente o Parlamento Europeu, o Conselho e a Comissão, estarão submetidos à intervenção processual caso nāo procedam ao correto pronunciamento sobre matéria de cunho comunitário, como previsto no artigo 232 do Tratado de Roma.

Art. 232 - Se, (..), o Parlamento Europeu, o Conselho ou a Comissäo se abstiverem de pronunciar-se, os Estados-membros e as outras Instituicoes da Comunidade podem recorrer ao Tribunal de Justiça para que declare verificada essa violação.

Este recurso só admissivel se a Instituição em causa tiver sido previamente convidada a agir. Se, decorrido o prazo de dois meses a contar da data do convite, a Instituição não tiver tomado posição, o recurso pode ser introduzido dentro de novo prazo de dois mese's.

Qualquer pessoa singular ou coletiva pode recorrer ao Tribunal de Justiça nos termos dos parágrafos anteriores, para acusar uma das Instituiçoes da Comunidade de nao lhe ter dirigido um ato que näo seja recomendação ou parecer.

A inovação que aqui presenciamos deve-se ao fato da Organização Internacional inserir-se no pólo passivo dos litigios nela apresentados.

Neste caso, o regime processual divide-se em uma fase pré-contenciosa, onde a parte prejudicada, que poderá ser tanto os Estados-membros quanto qualquer pessoa singular ou coletiva, solicita ao orgão comunitário, através de pedido explícito e fundamentado, que aja dentro de um prazo razoável ${ }^{41}$.

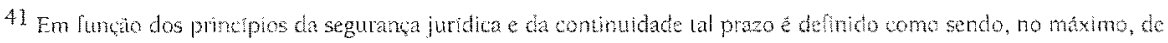
10 meses.
} 
Näo manifestando-se o órgão comunitário, ou manifestando em termos dilatórios, instaura-se uma fase contenciosa, tendo o trâmite processual comum, e chegando-se a um Acórdäo declaratório, no intuito de não conhecer o pedido ou que o orgão adote o ato cuja omissão originou a ação.

\subsubsection{Ação de Responsabilidade Extracontratual}

Tem como pressuposto a existéncia de perdas e danos causados pelas Comunidades Européias, resultantes de uma atividade ilegal dos seus órgãos ou agentes, estando prevista nos artigos 235 e 288 do Tratado de Roma:

Art. 235 (ex-art. 178) - O Tribunal de Justiça é competente para conhecer dos litigios relativos à reparaça dos danos referidos no segundo parágrafo do artigo 288.

Art. 288 (ex - art. 215) - A responsabilidade contratual da Comunidade é regulada pela lei aplicavel ao contrato em causa.

Em matéria de responsabilidade extracontratual, a Comunidade deve indenizar, de acordo com os principios gerais comuns aos direitos dos Estados-membros, os danos causados pelas suas Instituiçoes ou pelos seus agentes no exercicio de suas funçöes.

A responsabilidade pessoal dos agentes perante a Comunidade regulada pelas disposiçoes do respectivo estatuto ou do regime que thes e aplicavel.

Mais uma vez, a Organizaçăo Intemacional coloca-se no pólo processual passivo. Tal açăo fundamenta-se: na ilegalidade do comportamento imputado às Instituiçōes Comunitárias; na efetividade do dano; e, no nexo de causalidade entre o comportamento e o prejuizo alegado.

Destaca-se nesse caso o lato das pessoas singulares ou coletivas terem legitimidade ativa nesta açăo, independentemente de o terem em outro processo comunitário, como no caso do Recurso de Anulação. 
Mais uma vez o Acórdão tem teor declaratório, impondo medidas adequadas à equitativa reparação do prejuízo e considerando, neste caso, o dano emergente e o lucro cessante.

\subsubsection{Recurso de Anulação}

Terá como pólo passivo a Comissão ou o Conselho, estando previsto no artigo 230 do Tratado de Roma:

Arr. 230 - O Tribunal de Justica fiscaliza a legalidade dos atos (.) que näo sejam recomendaçóes ou parcceres (...).

Para o feito, o Tribunal de Justiça é competente para conhecer os recursos com fundamento em incompetencia, violação de formalidades essenciais, violação do presente Tratado ou de qualquer norma juridica relativa à sua aplicação, on em desvio de poder interpostos por um Estado-membro, pelo Conselho ou pela Comissão.

O Tribunal de Justiça é competente, nas mesmas condiçóes, para conhecer dos recursos interpostos pelo Parlamento Europeu e pelo Banco Central Europeu (...)

Qualquer pessoa singular ou coletiva pode interpor, nas mesmas condiçoes, recurso das decisóes de que seja destinatária e das decisöes que, embora tomadas sob a forma de regulamento ou de decisão dirigida a outra pessoa, the digam direta e individualmente respeito.

Os recursos previstos no presente artigo, devem ser interpostos no prazo de dois meses a contar, conforme o caso, da publicação do ato, da sua notificação ao recorrente ou, na falta desta, do dia em que o recorrente tenha tomado conhecimento do ato.

A admissibilidade do Recurso de Anulação depende da verificação da incompetência do órgão comunitário para estabelecer determinada norma, da violacão de formalidades essenciais para a elaboraça da norma comunitária, da violação dos Tratados comunitários ou de qualquer norma 
jurídica relativa à sua aplicação, ou em desvio de poder, sendo de dois meses $^{42}$ o prazo para a sua interposição.

No âmbito do Recurso de Anulação, o Acórdão do TJCE, que terá efeito erga omnes e retroativo poderá rejeitar o recurso interposto ou declarar, no todo ou em parte, o ato recorrido nulo e sem nenhum efeito.

\subsubsection{Recurso de Funcionarios}

O Tratado de Fusão, de 8 de abril de 1965, em seu artigo 24, 1, agrupou num único corpo os funcionários das trés Comunidades Européias, sendo aprovado, em 29 de fevereiro de 1968, pelo Regulamento 259/68, o Estatuto de Funcionarios das Comunidades ${ }^{43}$.

Art. 24 - 1. Os funcionários e outros agentes da Comunidade Européa do Carvão e do Aço, da Comunidade Economica Européia e da Comunidade Européia da Energia Atomica pasam a ser, (..) funcionários e outros agentes das Comunidades Européias e fazem parte da administração unica destas Comunidades.

Dado o elevado número de funcionários, são relativamente freqüentes os litigios que este interpoem contra as Instituições Comunitárias, sendo o Tribunal de Primeira Instância o órgão jurisdicional competente para julgalos, funcionando ora como tribunal administrativo, ora como tribunal trabalhista.

Só após esgotada a possibilidade de obter internamente, pela via hierárquica competente, a solução do litigio é que está o funcionário apto a recorrer, dentro do prazo de três meses da data da decisão interna, ao Tribunal de Primeira Instância.

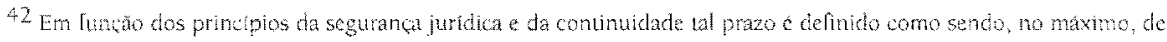
18 meses.

43 Este defhe funcionirio como sendo gualquer pesso gue tenha sido provida, nas condiobs previsas neste Estatuo, num lugar permanente de uma das Instituicoes das Comunidades mediante ato eserito da aulondade investida do poder de nomeacie.
} 
A partir dai, o Tribunal dispōe de amplos poderes para apurar os fundamentos do recurso interposto e, caso o julgue procedente, poderá anular o ato, reformar o ato substituindo-o pela sua própria decisão, ou a ordenar o pagamento de uma indenizaçäo ao luncionário lesado, sendo que, de sua decisão, caberá recurso, em matéria de direito, ao TJCE.

\subsubsection{Reenvio Prejudicial}

Previsto no art. 177, do Tratado de Roma, pressupöe uma decisão de orgão jurisdicional nacional suscitando questão ao Tribunal de Justiça das Comunidades Européias - TJCE.

Art. 177 - O Tribunal de Justiça é competente para decidir; a título prejudicial:

a) Sobre a interpretaça do presente Tratado;

b) Sobre a validade e interpretaçăo dos atos adotados pelas Instituiçoes da Comunidade e pelo BCE;

c) Sobre a interpretação dos Estatutos dos organismos criados por um ato do Consetho, desde que estes Estatutos o prevejam.

Sempre que uma questao desta natureza seja suscitada perante qualquer orgäo jurisdicional de um dos Estados-membros, esse órgăo pode, se considerar que uma decisão sobre essa questão $e^{2}$ necessária ao julgamento da causa, pedir ao Tribunal de Justiça que sobre ela se pronuncie.

Sempre que uma questão desta natureza seja suscitada em processo pendente perante um orgão jurisdicional nacional cujas decisöes não sejam suscetiveis de recurso judicial previsto no direito interno, esse órgão é obrigado a submeter a questão ao Tribunal de justiça.

Compete ao juiz originário do processo decidir, ex officio ou a pedido das partes, pela necessidade e momento iaeal do reenvio, fazendo-o por despacho com efeito suspensivo e enviando-o por correio à Secretaria do TJCE, em Luxemburgo. 
O Acórdäo pode versar tanto sobre questäo de validade ${ }^{44}$ ou ter efeito apenas interpretativo. Em ambos os casos, a decisão vincula o juiz nacional que recorreu ao IJCE, tem efeito retroativo, e dispensa às jurisdições nacionais a necessidade de submeterem, no futuro, idêntica questão ao T]CE

\subsubsection{Processo Especial}

Os atos das Instituiçoes Comunitárias são atos decisórios por sua propria natureza, não tendo, em principio, efeito suspensivo os recursos contra eles interpostos perante o Tribunal de Justiça das Comunidades Européias, a não ser que o requerente o impugne perante o Tribunal. Tal pedido deve especificar o objeto do litígio, as razöes da urgência, ben como os fundamentos de fato e de direito que o justifiquem. $O$ pedido $\dot{e}$, entäo, notilicado a parte contrária, que terá um prazo, fixado pelo Presidente, para pronunciar-se ${ }^{45}$.

A decisano terá a forma de despacho fundamentado, sendo irrecorrivel. Caso o pedido seja delerido, a sua execução pode ser condicionada à prestação, pelo requerente, de uma caução. Caso seja indeferido, a parte poderá, posteriomente, apresentar outro pedido, desde que fundamentado em latos novos.

Pode-se requerer ao Tribunal, ainda, o pronunciamento sobre uma exceça ou incidente de instancia, antes de conhecer do mérito da causa. Tal requerimento, formulado em separado, deverá conter a exposicão dos fundamentos, de fato e de direito, aos quais serào anexados os documentos que o apóiem.

Estados-membros e Instituiçoes podem intervir voluntariamente, até o inicio da fase oral, em qualquer litígio ${ }^{4}$. Tal pedido deverá conter: a

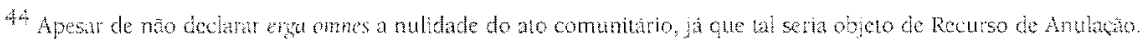

45 presidente pode deferir o pedido mesmo antes do pronunciameno da parte contrária, podendo tal deisase ser, postenomente, revogaliz ou modificada.

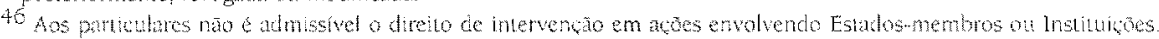

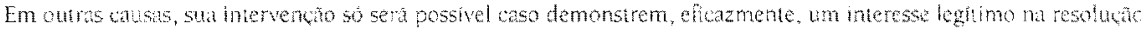
da causa subnetida a tribund.
} 
identificação do processo das partes; a identificaça do interveniente e sua residencia; o local, em Luxemburgo, onde serão eletuadas as notificações; e, a posição na qual o interveniente pretende intervir ${ }^{+3}$.

Caso os Estados-membros, as Instituiçoes ou qualquer pessoa física não tenham sido chamados a intervir no processo, podem deduzir oposição de terceiro contra o Acórdão, quando este prejudique seus direitos. Tal oposiça deve ser apresentada por escrito, no prazo de um mês contado a partir da notificação do Acórdão.

Por fim, é permitida a revisão do Acórdão do Tribunal, desde que fundamentada na descoberta de fatos novos, suficientemente importantes para o julgamento do litígio. Tal revisão poderá ser requerida dentro do prazo de 10 dias, após a publicação da decisão.

\section{O Mercosul}

E de conhecimento geral que o projeto de integração da América Latina é tão antigo quanto a formaçăo dos Estados Nacionais na região. Ao menos, em relação à América Hispânica, sempre houve um sentimento em prol da formaçäo de uma comunidade supranacional forte.

A primeira grande tentativa articulada para a Integração Econômica da região se deu, no entanto, com o surgimento e divulgaçăo do pensamento cepalino, que diagnosticou as vantagens da Integração. A divulgação desta idéia, juntamente com o processo de liberalização comercial desencadeada pelo General Agrement on Iariffs and Trade - GATT, tendo como base a cláusula da nação mais favorecida, acabou gerando a Associação LatinoAmericana de Livre Comércio - ALALC, quando se aproveitou a intenção da Argentina, Brasil, Chile e Uruguai, em criar uma Area de Livre Comércio ${ }^{48}$, e se decidiu pela formação de um organismo que viabilizasse o

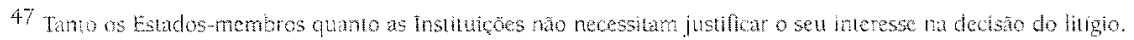

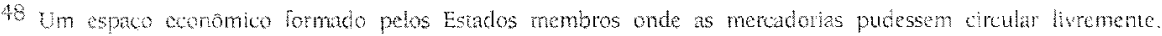

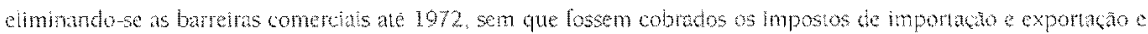
sem que houvesse a imposican de medidus de efolo equivalente.
} 
desenvolvimento desta, em toda a região, de forma gradual e cadenciada. Criou-se, então, pelo Tratado de Montevidéu, de 18 de fevereiro de 1960, a ALALC, que incluiu, além dos quatro países supracitados, o México, Paraguai e Peru e, posteriormente, a Bolívia, Colómbia, Equador e Venezuela.

Tendo, inicialmente, obtido o desgravamento tarifário dos produtos tradicionalmente comercializados na região, com o tempo, todavia, este organismo acabou emperrando nas negociações de produtos novos, de menor complementaridade economica. Entre 1961 e 1978, o comércio entre os países membros, passou de US\$ 250 milhões, para US\$23,3 bilhōes, nos anos 80 porém, a ALALC passou a sofrer as consequências da divida externa, da recessão e da hiperinflação de seus membros. Com a interrupção no fluxo de novos capitais e a imposição de Planos Ortodoxos de Ajuste Econômico, defendidos pelo FMI, o comércio inter-regional cai para US $\$ 20$ bilhões. A ALALC é então substituída pela Associação Latino-Americana de Desenvolvimento e Integração - ALADI, criada pelo Tratado de Montevidéu de 1980, uma organização menos preocupada com o estabelecimento de áreas de Livre Comércio e mais voltada à consecuçăo de acordos bilaterais de caráter setorial, que não se estendiam automaticamente aos Estadosmembros ${ }^{49}$.

O Tratado de Montevidéu de 1980, criou diversos mecanismos, que visavam a liberaçâo do intercâmbio comercial intra-regional, sobretudo através da reduçăo de Barreiras Tarifárias, com o estabelecimento de margens de preferência e, com a eliminação de Barreiras Não-Tarifárias. Três deles são de natureza regional: a Preferência Tarifária Regional - PTR; O Programa de Recuperação e Expansão do Comércio - PREC; e, as Listas de Aberturas de Mercados - LAMs. Há ainda uma outra categoria, de âmbito apenas parcial, bilateral ou plurilateral, como os Acordos de Renegociação do Patrimônio Histórico da ALALC; os Acordos Comerciais; os Acordos de Complementação Econômica-ACEs; e, acordos ou ajustes de abertura de mercado.

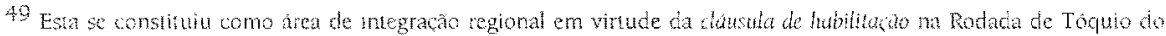

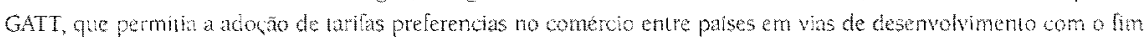
de reduzir ou eliminar mutuamente os impedimentos de seu comércio recíproco 
O desmantelamento das Barreiras Não-Tarifárias, prometido em principios da década de 80 , sempre tropeçou na continuada Política Econômica Protecionista da maior parte dos paises da região, sendo que, até muito recentemente, os compromissos assumidos, destinados a eliminar tais Barreiras, eram simplesmente ignorados por países voltados para o ajustamento unilateral de suas próprias dificuldades de Balança Comercial ${ }^{50}$.

Com o incremento da formação da Uniāo Européia, reacendeu-se a chama da Integração Latino-Americana. Nesse sentido, Brasil e Argentina deram os passos iniciais em novembro de 1985, quando, através da Declaração de Iguaçu, os presidentes José Sarney e Raul Alfonsin formalizaram uma Comissão Mista, com o objetivo de integrar as duas economias. Os trabalhos dessa Comissão, levaram à assinatura da Ata para a Integração Argentino-Brasileira, em 1986, que instituiu o Programa de Integração e Cooperaçăo Econômica - PICE, com o objetivo de promover uma abertura seletiva e estimular a complementação setorial das duas economias gradualmente, de modo a permitir uma adaptaça progressiva dos habitantes e das empresas de cada Estado à nova legislação econômica e às novas condições de competitividade.

Em 1988, o Brasil e a Argentina comprometeram-se, através do Tratado de Integração, Cooperação e Desenvolvimento, a remover todas as Barreiras, Tarifárias e Näo-Tarifárias, ao comércio de bens e serviços, mediante a negociação de Protocolos Adicionais ao Acordo de Alcance Parcial de Renegociação das Preferências outorgadas no período de 1962 a 1980, num prazo de dez anos ${ }^{51}$. Simultaneamente, iniciou-se uma harmonização gradual de políticas internas, necessárias ao Mercado Comum. O Tratado previa, ainda, a adesão de Estados-membros da ALADI, transcorridos cinco anos de sua entrada em vigor. com isso, as relaçóes comerciais entre Brasil e Argentina, cresceram 39,6\%, em relação ao periodo

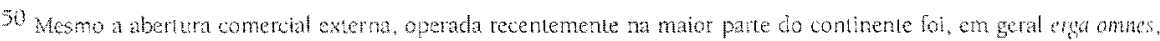
sem bezefuci, portanto, o comercin inua-regional.

51 A pant da lomm assmados 24 polocolos sobre temas diversos como: produtos alimenlistos industializados,

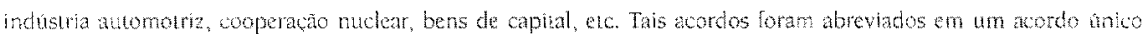

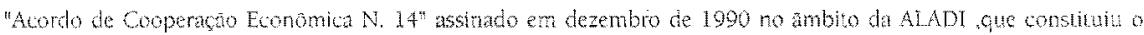
velencial adotato posteriomente no Tratado de Assmcáo.
} 
1986-87, reduzindo o tradicional desequilíbrio da Balança Comercial dos dois países.

Com a mudanca de governo nos dois paises, e diante de uma tendência mundial à crescente globalização, o processo de Integração teve novo impulso. A 6 de julho de 1990, os presidentes Fernando Collor e Carlos Menén assinaram a Ata de Buenos Aires, lixando o prazo de 31 de dezembro de 1994 para a conformação definitiva do Mercado Comum entre Brasil e Argentina. Nesse documento, foram definidas as bases do futuro Mercado Comum, ainda em âmbito bilateral, iniciando-se entendimentos que permeariam todos os aspectos da atividade reguladora dos Estados. Em agosto do mesmo ano, Paraguai e Uruguai foram convidados a juntar-se ao processo. Sendo assim, os quatro países assinaram, a 26 de março de 1991. - Tratado de Assunção, para a formação do Mercosul ${ }^{52}$. Tal acordo internacional foj aditado por diversos anexos e protocolos, com ênfase para - Protocolo de Ouro Preto, de 17 de dezembro de $1994^{53}$ que, pela impossibilidade de efetivaçăo do Mercado Comum dentro do prazo previsto, criou uma nova estrutura institucional, optando pela implementação gradativa de uma União Aduaneira em 1.1.2005 e dotando o Mercosul de personalidade juridica de Direito Intemacional Público.

Mercosul, que capta influências da experiencia européia, constitui uma organização completamente nova, possuindo características peculiares ${ }^{3+}$. Não há em seu âmbito um ordenamento jurídico autônomo, mas pode-se afirmar que há um direito de integração, que engloba a estrutura institucional do Mercosul.

\subsection{O Sistema Juridico Integracionista}

O Capítulo II do Tratado de Assunção, estabelecia, para o período de transiçäo, a existência de dois orgãos responsáveis pela ação jurídico-

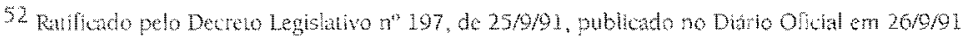

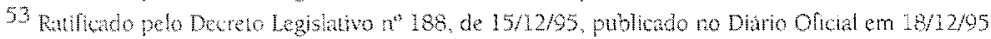

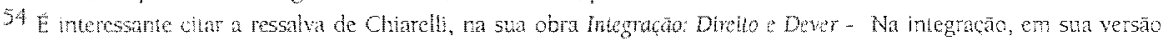

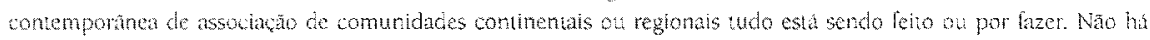

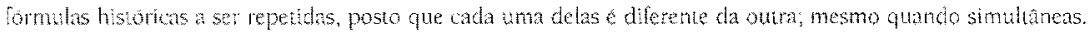


administrativa e executiva do MERCOSUL: o Conselho do Mercado Comum - $\mathrm{CMC}^{55}$, órgão superior de caráter político, formado pelos Ministros das Relaçoes Exteriores dos paises membros, e responsável pela conduça politica pela tomada de posiçóes; e, o Grupo Mercado Comum - GMC, orgão executivo, formado por representantes dos Ministérios das Relaçoes Exteriores, da Economia, ou de seus equivalentes Bancos Centrais, que seria responsavel para: velar pelo cumprimento do Tratado; tomar as providéncias necessärias ao cumprimento das decisoes adotadas pelo Conselho; propor medidas concretas tendentes à aplicaça do Programa de Liberaça Comercial, à coordenaçăo de políticas macroeconômicas e à negociaça de Acordos entre terceiros; e, fixar programas de trabalho que assegurem avanços para o estabelecimento do Mercado Comum. Havia, ainda, a previsăo de uma Secretaria Administradiva.

Prolocolo de Ouro Preto, assinado em 17 de dezembro de 1994 , cuidou da reformulaçăo estrutura do Mercosul. Manteve aqueles orgãos criados pelo Tratado de Assuncão, acrescentando mudanças no sentido de lazer uma adaptaça aos acontecimentos ocomidos durante o processo de integração, adicionando os seguintes órgãos: Comissão de Comércio do Mercosul e o Foro Consultivo Econômico-Social.

Dentro dessa estrutura, pode-se dividir os órgãos em principais, dotados de capacidade decisória, e satélites, cujas manilestaçes consticuem apenas recomendaçoes.

Os principais seriam: Conselho Mercado Comum, Grupo Mercado Comum e Comissão do Comércio do Mercosul.

Os satélites seriam: Comissão Parlamentar Conjunta, Secretaria Administrativa e Foro Consultivo Econômico-Social.

Os órgäos continuaram com a mesma natureza intergovernamental, com decisöes consensuais e unânimes, não sendo acolhida a

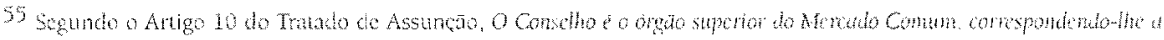

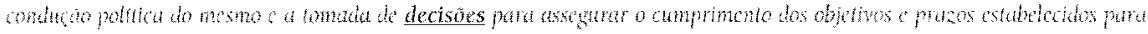

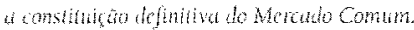


supranacionalidade. Seus membros continuam sendo representantes dos Estados $e$ as normas continuam não possuindo aplicação imediata ${ }^{56}$, havendo necessidade de serem ratificadas pelos Parlamentos nacionais, apesar de algumas serem obrigatórias para os Estados-Partes.

Contudo, tal estrutura é passível de ser modificada. O Protocolo, em seu art. 47, prevê a revisão dessa estrutura, além das atribuições específicas de cada órgão, através de conferência diplomática. Nesse sentido, deve-se atentar para a questão da supranacionalidade, considerada necessária para se aprofundar no processo de integração e que é vista com receio pelo fato de acarretar cessão de parcela, ainda que mínima, da soberania.

De acordo com o art. 41 do Protocolo de Ouro Preto, as fontes do Direito da Integração são:

1. o Tratado de Assunção, seus protocolos e os instrumentos adicionais ou complementares;

2. os acordos celebrados no âmbito do Tratado de Assunção e seus protocolos;

3. as decisões do Conselho Mercado Comum, as resoluções do Grupo Mercado Comum e as diretrizes da Comissão de Comércio do Mercosul, adotadas desde a entrada em vigor do Tratado de Assunção.

Essas normas, apesar de serem de aplicação obrigatória para as partes, não podem ser consideradas comunitárias, posto que não são diretamente aplicáveis nos Estados e não há nenhum órgão que as imponha., devendo sujeitar-se à ratificação para serem incorporadas respectivos ordenamentos internos. Assim, elas constituem normas de Direito Internacional e não se pode lalar em ordenamento comunitário em termos de Mercosul; existe tão somente, como vemos, um Direito da Integração.

Há, desta forma, como vislumbrarmos a existência de um Direito Originário e Derivado da Integração.

Atualmente, além do Tratado de Assunção e do Protocolo de Ouro Preto, os principais instrumentos jurídicos do Mercosul no que se refere a

\footnotetext{
56 A supranacionalidade, como jĭ vimos, tem como características principais a aulonomia dos órgãos petante os Estados membros da organizaçăo, alem de normas auto-aplicaveis, que prevalecem sobre as normas nacionais.
} 
Protocolos e Acordos de Cooperação são:

- Protocolo de Brasilia (Dec. CMC 01/91): relativo ao sistema de solução de controvérsias no âmbito intra-comunitário, promulgado no Brasil pelo Decreto ${ }^{\circ} 922$, de 13 de setembro de 1993;

- Protocolo de Lãs Leñas (Dec. CMC 05/92); protocolo de cooperação e assistência jurisdicional em matéria civil, comercial, trabalhista e administrativa, promulgado no Brasil pelo Decreto $\mathrm{n}^{\circ}$ 2.067. de 12 de novembro de 1996;

- Protocolo de Buenos Aires (Dec. CMC 01/94): acerca da jurisdição internacional em matéría contratual, promulgado pelo Decreto $n^{\circ} 2.095$, de 17 de dezembro de 1996;

- Protocolo de Ouro Preto (Dec. CMC 27/94): sobre medidas cautelares, promulgado pelo Decreto $n^{\circ} 2.626$, de 15 de junho de 1998;

- Protocolo de Fortaleza (Dec. CMC 21/96): que trata da defesa da concorrência no âmbito do Mercosul, promulgado pelo Decreto $n^{\circ}$ 3.602, de 18 de setembro de 2.000

- Acordo de Livre Comércio Chile - Mercosul, aprovado pelo Decreto Legislativo $n^{\circ} 096$, de 25 de junho de 1996;

- Acordo Quadro Inter-regional Uniāo Européia - Mercosul, aprovado pelo Decreto Legislativo $\mathrm{n}^{\circ} 010$, de 4 de fevereiro de 1997

- Acordo de Complementação Econômica Mercosul - Bolivia, aprovado pelo Decreto Legislativo n 019, de 29 de abril de 1997.

\subsection{Solução de Controvérsias}

O Mercosul apresenta um sistema de solução de controvérsias peculiar. Previsto a partir do Protocolo de Brasilia, de $1991^{57}$, os litígios

57 Rathcado pelo Decteto legistativo n8892, e promulgado pelo Decreto n $922 / 93$. 
oriundos das práticas econômicomcomerciais deste bloco de integração abrangem Estados-parte e, até mesmo, particulares, apesar de näo apresentar qualquer garantia jurídica para o cumprimento de suas decisöes.

Boa parte dos juristas brasileiros afirmam a necessidade da criaça de uma corte supranacional, como forma de assegurar aos Estados-membros, às entidades comunitárias, empresas e individuos, imparcialidade e justiça.

Como afirma Fernando de Magalhães Furlans" é certo que a Corte do Mercosul não seria a única jurisdição habilitada a aplicar o direito comunitário. órgãos do Poder Judiciário de cada um dos estados membros seriam, também eles, orgăos jurisdicionais comunitários, na medida em que:

- permaneceria no âmbito das suas competências a fiscalização da execuçâo administrativa do direito comunitärio, vez que esta seria, em sua essência, confiada aos órgãos da administraça dos Estadosmembros;

- e um grande número de disposiçoes dos tratados e do direito derivado (regulamentos, decisoes, etc.) criam direitos individuais em beneficio dos nacionais dos Estados-membros, cabendo aos judiciarios nacionais a sua garantia.

Segue o autor alimando que, não há comunidade, nem mesmo a familiar, que vingue se não houver regras e estas forem decididas em conjunto, aplicadas de comum acordo e, quando necessario, analisadas, condenadas ou aperfeicoadas em colegiado. Todas as partes envolvidas devem aceder. A supremacia das leis nacionais deve ser respeitada, conquanto não conflitem com os tratados e o chamado "acquis communautaire", ai incluidas as leis e o regramento juridico comunitário em geral. Para tanto, os estados-membros deverão promover modificaçoes em seu sistema jurídico intemo, conferindo prevalencia aos tratados do Mercosul e buscar a harmonização legislativa. Ao Poder Judiciário dos estados-membros compete reconhecer a precedência da lei comunitária no caso de conflito entre os dois sistemas juridicos, o nacional e o comunitário.

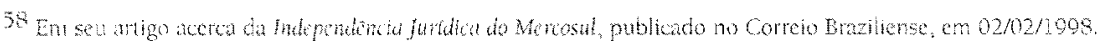


Concluindo que há argumentos no sentido de que, no caso brasileiro, os diretos e garantias fundamentais estariam ameaçados com a criação de uma Corte do Mercosul. O artigo $5^{\circ}, \mathrm{XXXV}$, da Constituição Federal dispóe que a lei não excluirá da apreciação do Poder Judiciário lesão ou ameaça a direito. Contudo, parece-nos que a criação de um tribunal do Mercosul, dedicado à guarda dos princípios de direito e à observância do sistema jurídico comunitario, de forma alguma constituiria uma afronta aos direitos e garantias do cidadão, ao contrário, amplia-los-ia. O próprio artigo $5^{\circ}$, em seu inciso LV, preve que aos litigantes, em processo judicial ou administrativo, e aos acusados em geral são assegurados o contraditorio e a ampla defesa, com os meios e recursos a ela inerentes. O advento de uma Corte do Mercosul não furtaria dos órgãos da Justiça Federal brasileira a competência sobre temas de direito internacional. O órgão julgador do Mercosul não interferiria nas leis domésticas, salvo quando estas colidissem com disposições legais comunitárias. Ao Tribunal do Mercosul incumbiria a tarefa de evitar que o direito comunitário fosse interpretado e aplicado à maneira de cada um, de garantir que a lei comum preservasse o seu caráter e a sua natureza comunitários e de assegurar que a lei fosse idèntica para todos. É tempo de agir, a competição internacional é cada vez mais pungente. Somente os mais fortes, coesos e organizados terão chances. O Mercosul, como organização democrática supranacional e pelo bem do seu futuro, não pode se abster de reconhecer a necessidade e oportunidade do estabelecimento de um órgão jurisdicional com poderes amplos e concretos.

Entre os estudiosos do processo de integração mercosulina há consenso que o Tratado de Assunção não é um "tratado marco", como o foi - Tratado de Roma, mas sim um "tratado de trânsito", destinado a construir e não constituir de uma só vez, o mercado comum. Enquanto isto, a solução dos litigios fica entregues a métodos tradicionais do Direito Internacional Privado, que, como afirma Pavan ${ }^{59}$ näo é ferramenta apropriada para os processos de integração. Segundo o mesmo autor, para licar-se apenas em

59 PAVAN, Luiz C. A soluça de controvérsias no mercosul. [Flonimópulis]: UDESCESAG, 2000, p. 25. 
dois exemplos, é completamente irracional o tratamento dado pelos paises diferentes do Mercosul ao tópico dos laudos arbitrais internacionais, assim como também é incompreensivel que não se haja adotado de forma ampla a Convenção de Viena sobre Compra e Venda de Mercadorias em todo o território integrado. Os países que integram o Mercosul, na qualidade de sócios plenos (Argentina, Brasil, Paraguai e Uruguai) e seus membros associados (Chile e Bolívia), têm em suas bases juridicas mais coincidencias que pontos atrito, pois as fontes de nossa civilização são a cultura cristã e o direito romanó. Porém, quando se analisa as adesōes de cada às obras de codificaçäo latino-americanas temos que Argentina, Paraguai Uruguai e Bolívia estão vinculados ao Tratado de Montevidéu, de 1889 , não tendo Bolívia aderido à atualização de 1940. Por outro lado Brasil, Chile e Bolivia estão afiliados ao Código Bustamante, de 1928 constituindo isto a primeira grande assimetria entre os sócios. O mesmo acontece nas convençŏes internacionais relativas às disposiçōes de compra e venda, contratação internacional, arbitragem etc, com os mais distintos níveis de adesão de cada país. Tradicionalmente, dos sócios no projeto de integração, o Brasil é o país que mais reage à admissão de direito estrangeiro em sua ordem interna, mas o próprio Mercosul está forçando uma mudança de atitude. Isto se pode verificar, por exemplo:

- No Protocolo de Brasilia se verifica uma certa dose de admissão ao princípio da supranacionalidade, pois o laudo arbitral obriga os Estados-Partes a uma decisāo tomada por peritos desvinculados de seus paises, sob pena de sofrer medidas compensatórias temporárias;

- no Protocolo de Buenos Aires, introduz-se na regiäo a aceitação do princípio da autonomia da vontade, a respeito dos negócios juridicos efetuados entre pessoas de direito privado;

- no âmbito intemo brasileiro, a Lei $n^{\circ} 9.307$, de 26 de setembro de 1996, admite a validade dos julgados e laudos dos tribunais arbitrais proferidos no exterior, sob as condiçōes nela fixadas. 
Por tudo que se tem demonstrado, o Mercosul está desintonizado com o sistema de comércio internacional, não tendo sequer um instrumento para dirimir seus eventuais conflitos comerciais ${ }^{60}$.

Näo bastasse todos estes problemas, temos, ainda, uma enorme resistência por parte dos Tribunais Internos em acatar as decisões mercosulinas, como se vê, pela análise de excertos de julgados de tribunais brasileiros, como demonstrado no quadro abaixo.

\section{Jurisprudência Brasileira Supremo Tribunal Federal - STF}

- Agravo Regimental em Carta Rogatória - AGRCR - 7613 (3.4.97) Just. Rog: Juizo Nacional de Primera Instancia en Materia Civil n. 45 de Buenos Aires

\section{Rel. Min. Sepúlveda Pertence}

.. O Protocolo de Las Leñas ("Protocolo de Cooperaçäo e Assisténcia Jurisdicional en Materia Civil, Comercial, Trabalhista, Administrativa" entre os paises do Mercosuli) não afetou a exigéncia de que qualquer sentença estrangeira - à qual e de equiparar-se a decisão interlocutória concessiva de medida catelar - para tornar-se exeqüivel no Brasil, há de ser previamente submetida à homologação do Supremo Tribunal Federal, o que obsta à admissäo de seu reconhecimento incidente, no foro brasileiro, pelo juizo a que se requeira a execução...

\section{TRIBUNAL REGIONAL FEDERAL - IRI (1 ${ }^{\text {a }}$ Região)}

- Apelação em Mandado de Segurança (3.3.98)

\section{Relator - Juiz Tourinho Neto}

... as normas gerais estabelecidas pela Decisão do Mercosul no 18 de 1995, não podem revogar as normas especiais previstas nos Decreto-leis 37, de 1966, e 1455, de 1976, principalmente por aidarem da mesma problematica.

\footnotetext{
50 PAVAN, LUiz C. A solução de controversias no mercosul. [Florianópolis]: UDESCESAG, 2000, p. 30 e sas.
} 


\section{TRIBUNAL REGIONAL FEDERAL - TRF (4a Região)}

- Liminar suspendendo a importação de arroz argentino e uruguaio no território nacional $(25.4 .00)$

\section{Presidente da $4^{*}$ Turma - Juiza Silvia Goraieb}

... a União năo estabeleceu nenhuma medida que assegurasse o equilibrio comercial nem outro controle sanitário para verificar se a qualidade do arroz importado compativel com que a que o povo brasileiro precisa para se alimentar. (..) a Constituição estabelece que a politica agricola deverá ser planejada e executada na forma de lei...

\section{SUPERIOR TRIBUNAL DE JUSTICA - STJ}

- Petiçăo n. ${ }^{\circ}$ 1273/RS - Registro n. $2000 / 0040618-0$ (08.06.2000)

\section{Presidente do STJ - Paulo Costa leite}

... o Mercosul näo possui o status de ente supranacional, pois näo apresenta uma estrutura juridica eficiente de modo a conciliar a integralização dos Estados. Até hoje não tem direito próprio, nem órgãos de decisão, confundindo-se com o direito e governos participantes do bloco, pois é atraves deles que as regras são fixadas e só depois de inseridas na ordem jurídica de cada país adquirem força impositiva. (...) ... é uma organização politica de direito internacional do tipo intergovernamental. (..) 0 Mercosul, não dispondo de tribunal com funçoes verdadeiramente jurisdicionais, pois as divergências säo resolvidas por juizo arbitral, näo pode, assim, impedir o conhecimento da justiça brasileira sobre fatos ocorridos em sua jurisdição. (..)

... a suspensâo das importaçoes interfere na própria credibilidade da politica externa brasileira, colocando-a em risco, ... além de comprometer o processo de consolidacáo do MERCOSUL, o que se revela gravemente danoso para a economia nacional. Não é preciso avançar mais, até porque implicaria incomportável exame de questões de mérito, inajustável aos limites do juizo excepcional da suspensão do provimento da cautelar. 


\section{Conclusão}

Como se verificou, a integração é um fenômeno complexo, caracterizado pela aproximaçăo político-econômica de diversos Estados, através da ampliação de seus mercados, a partir da celebração de tratados internacionais com a cessão ou renúncia de algumas de suas competências em favor da Organizaçăo Internacional a ser criada.

No àmbito desta entidade, passou a desenvolver-se um novo Sistema Juridico, intermediário entre os direitos internos dos Estados e as competências por eles cedidas à Organização Internacional. Se o mesmo for autonomo, tiver primazia sobre as normas de Direito interno e gerar diretamente efeitos a todos submetidos à sua jurisdição, teremos o Direito Comunitário. Se, todavia, o mesmo depender de manifestação dos órgăos internos dos Estados que compõem a Organização Internacional já que é considerado como um ramo do Direito Internacional Público, teremos o Direito da Integração. Um representa o modelo da União Européia, outro o modelo do Mercosul.

No modelo europeu, temos, já a partir dos tratados originários, a criação de tribunais supranacionais, incumbidos da solução dos litígios envolvendo não só os Estados-membros da Organização Internacional, mas, até a própria Organizaça e seus órgảos e, inclusive, particulares. Suas decisões gozam de autonomia, são aplicadas sem necessidade de qualquer ato prévio de incorporação e prevalecem sobre a norma interna de qualquer Estado-membro da Organização Internacional. Em função disto, possuem um regime processual próprio, que se divide em Processo Comum e Processo Especial, com princípios, regime lingüístico, prazos, fases e decisão diferente dos praticados pelos estados que compōem a Organização Internacional, até mesmo pelo fato destes representarem sistemas distintos, uns vinculados à Common Law, outros ao Romano-germânico.

Já o sistema mercosulino, a princípio até menos árduo de ser implementado, pois todos os Estados-membros da Organização Internacional vinculam-se ao sistema romano-germânico, caracteriza-se pela elaboração de um sistema de solução de controvérsias posterior a do tratado 
originário, que é de 1991, o Protocolo de Brasilia, que só entrou em vigor em 1993. Por ele, os litígios oriundos das práticas econômico-comerciais deste bloco de integraça abrangeriam Estados-parte e particulares, excluindo, de forma no mínimo estranha, a Organização Intemacional do pólo processual. Além do mais, não apresenta qualquer garantia juridica para o cumprimento de suas decisòes, contando, por fim, com enorme resistência dos tribunais internos em acatar as suas decisoes.

Concluimos então que, apesar da motivação comum que levou Estados soberanos a aproximarem as suas politicas econômicas através da celebracaão de tratados internacionais, o modelo processual europeu $e$ mercosulino é completamente distinto na forma de solução de suas controvérsias e na sua aceitação pelos órgãos de jurisdição dos Estadosmembros, fato este que, Jogicamente, reflete não só em sua eficácia juridica, mas, principamente, no modelo de integraçăo adotado pelos referidos Blocos.

\section{BIBLIOGRAFIA}

ALMEDDA, Elizabeth A. P. de A supranacionalidade no Mercosul, in La integración hacia el siglo XXI. Encuentro Internacional de Derecho de la America del Sur (org. Broença, Alencau M. e Biocca, Stella M.). pelotas. RS. Brasil: Educat, 1996 a.

ALMEIDA, Elizabeth A. P de. "O ordenamento juridico da União Européia e do Mercosul", in Stahringer, Ofélia (coord.) O Mercosul en el nuevo orden mundial. Buenos Aires: Ediciones Ciudad Argentina, $1996 \mathrm{~b}$

ALMEIDA, Elizabeth A. P. de. Mercosul e união européia: estrutura juridico-institucional. $2^{3}$ ed. Curitiba: Junuá, 1999

ANDRADE, Fábio S. de "Codificación y Mercosul: Uma equación posible" in Mercosur- Perspectivas desde el derecho privado, parte segunda. Buenos Aires: Ed. Universixiad, 1.996

ANTUNES, Antonio J. C. - "La red de acuerdos de libre comercio". Buenos Aires: Gazeta Mercantil Latinomericand-GMLA, n. 35 , de 1 a 7.12 .96

BASZ, Victoria - "El rol del Derecho Internacional. Transformaciones juridicas en el proceso de Antegraçäo, in Mercosur- Perspectivas desde el derecho privado, parte Segunda. Buenos Aires. Ed. Universidad, 1996

DE KLOR, Adrana Dreyzin - "El derecho internaciona! privado en las relaciones Mercosur-Unton Europea", in Revista Juridica. Universidade Regional de Blumenau. Blumenau. SC: Académicas Publicaçes, 1998 
DEUTSCH, Karl. Analise das relaçōes internacionais. Brasilia: Ed. UnB, 1982.

DROMI, Roberto, EKMEKDIAN, Miguel A e RIVERA, Julio C. Derecho comunitário- régimen del mercosur. Buenos Aires: Ediciones Ciudad Argentina, 1996.

FELDESTEN DE CARDENAS, Sara L. Ll sistema juridico del mercosur: jurisdicción internacional en materia contractual". Buenos Aires: Abeledo-Perrot, 1995.

HARGAIN, Daniel- "Contractos comerciales en el Mercosur. Ley aplicable y juiz competente. Buenos Aires: Revista de Derecho del Mercosur n. ${ }^{\circ}$, maio de 1997

KEGEL, Patricia L. - "Os objetivos do Mercosul e sua estrutura juridico institucional a- pós o Protocolo de Ouro Preto", in la integracion hacia el siglo XXI. Encuentro Internacional de Derecho de la América del Sur (org. Proenca, Alencar M. e Biocca, Stella M.). Pelotas. RS. Brasil: Educar, 1996

LIPOVETZK, Jaine C. e Daniel A.- "Soluçăo de Controversias" In. Mercosul: Estrategias para a integraço. Sắ Paulo: Ed. LTR, 1994

PABSI, Haroldo. Mercosul: direito da integração. Rio de Janeiro: Forense, 1998

PAVAN, Luiz C. A solução de controversias no mercosul. Florianópolis: UDESCLSAG, 2000. Năo publicada.

PESCATORE, Pierre. Derecho de la integracion de américa latina. Buenos Aires:

BID-INTAL, 1983.

SILVA, Roberto L. Direito econômico internacional e direito comunitário. Belo Horizonte: Del Rey, 1995.

SILVA, Roberto L Direito comunitario e da integraçào. Porto Alegre: Śntese, 1999.

SILA, Roberto I... Direito internacional público. Belo Horizonte: Inédita, 199.

ROSA, Luis E: Franceschini da Mercosul e a funcão judicial: realidade esuperaçăo. Săo Paulo Editora Revista dos Tribunais, 1997 . 